\title{
Theobalds, Hertfordshire: The Plan and Interiors of an Elizabethan Country House
}

\author{
by EMILY COLE
}

Theobalds, the creation of Sir William Cecil (1520/1-98), first Baron Burghley, has long been a spectral presence in the history of Elizabethan country houses. From the time of its completion in 1585 until the time of its destruction shortly after 1650, less than seventy years passed. During that period, Theobalds gained a reputation throughout Europe, befitting its status as the principal country home of Elizabeth I's principal minister and, from 1607, a major early Stuart royal palace. It was the country house most favoured by Queen Elizabeth, and was visited by all the major court and political figures of the Elizabethan, Jacobean and Caroline periods. It was here that King James I was received by the royal household and court on his journey south from Scotland in 1603, and here that he died in 1625, his son Charles being proclaimed king at the palace's gates.

In architectural terms, Theobalds, which was located near Cheshunt in Hertfordshire, was hugely innovative and influential. Lord Burghley used the house as a platform to demonstrate his power, taste and knowledge, lavishing money on its building and decoration. At Theobalds, architectural features including balconies and compass windows made some of their earliest documented appearances in English architecture, while the house was rivalled by none for its number of loggias, long galleries and rooftop walks. Theobalds set new standards in its scale, plan, style and fitting out, and was imitated in numerous late sixteenth- and early seventeenth-century buildings in England and further afield. Most famously, these include Holdenby in Northamptonshire (1571-83) and Audley End in Essex (c. 1604-14) - both later adopted as royal palaces - but the information set out in this article helps to show that Theobalds's plan and architecture also influenced houses including Wollaton Hall in Nottinghamshire (1580-88), Knole in Kent (as rebuilt c. 1604-08), and Hatfield in Hertfordshire (1607-12). It would be no exaggeration to state that Theobalds was probably the most significant country house of the Elizabethan period. As a result, new discoveries relating to it have the potential to contribute to our knowledge of architecture of the whole era.

To date, Theobalds has attracted only limited scholarly attention, based on a belief that - as the house was demolished so long ago - its appearance and plan could 
never be accurately reconstructed. Certainly, it is true that only few traces of this remarkable building survive today, ${ }^{1}$ and there are no known contemporary depictions of the house, aside from a handful of designs and two rough and inaccurate sketches. ${ }^{2}$ Yet, in comparative terms, Theobalds is extraordinarily well documented, and the phases of its design and construction can be reconstructed with some confidence. The first scholar to attempt this was Sir John Summerson, who published a seminal article in 1959. ${ }^{3}$ Since then, further work has been published on the years when Theobalds served as a royal palace, ${ }^{4}$ on its architectural influence, ${ }^{5}$ its gardens and landscape setting, ${ }^{6}$ and its decorative schemes. ${ }^{7}$ However, the majority of the primary evidence relating to Theobalds remains unexplored, and there are major aspects of the house which have yet to be investigated. Most notably, its plan has not been established beyond the general details set out by Summerson and then repeated, with further observations, by Ian Dunlop. ${ }^{8}$

This article aims to reconstruct the plan of Theobalds, using evidence provided by primary sources such as the Cecil Papers at Hatfield House, the Royal Works accounts, descriptions of visitors, and the detailed parliamentary survey of April 1650. No inventories recording the contents of the house are known to survive, but the layout of Theobalds is further illuminated by a unique series of documents, all clearly authored by Lord Burghley. These are schedules showing how Queen Elizabeth, her attendants and courtiers were to be accommodated at the house for the royal visits of 1572, 1577, 1583 and $1591 .{ }^{9}$ Although these sources have generally been very little studied, they were used by Summerson. However, his work focused on the development, phasing, design process, overall layout and general appearance of Theobalds. In his article of twenty pages, only around four described the house's 'interior disposition'. ${ }^{10}$ Summerson readily acknowledged the limited scope of his paper: he noted that the parliamentary survey, for instance, provided more information, 'but there would be no point in cataloguing these details in a paper which aims only at a general architectural description' ${ }^{11}$

Here, Summerson's findings have been taken further and extended through a more detailed study of the primary material relating to the house's plan and decoration, including some sources that were not used (or at least cited) by Summerson. ${ }^{12}$ The full value of these sources, especially the schedules of accommodation and the parliamentary survey, has been exploited here for the first time. While the outcome is not a comprehensive reconstruction of every detail of the plan of Theobalds, it is more than any other scholar has achieved so far. Indeed, this article shows that, far from being poorly understood, the plan of Theobalds is perhaps better documented than that of any other Elizabethan courtyard house of its status.

This article focuses on the two principal courtyards of Theobalds - the Middle Court and Conduit Court - the ranges of which included the public rooms and lodgings. The rooms' positions and arrangements will be the emphasis, but their decoration will also be touched upon. Although no contemporary upper-floor plans of Theobalds as built are known to survive, ${ }^{13}$ there are drawings by John Thorpe of $c$. 1606, showing most of the ground floor (Fig. 1) and basement as completed. ${ }^{14}$ Together with the large body of primary evidence, these allow for conjectural reconstructions of all of Theobalds's floor levels (Figs 2-6), attempted here for the very first time. ${ }^{15}$ A reconstruction of the house's exterior has also been attempted (Fig. 7). ${ }^{16}$ 


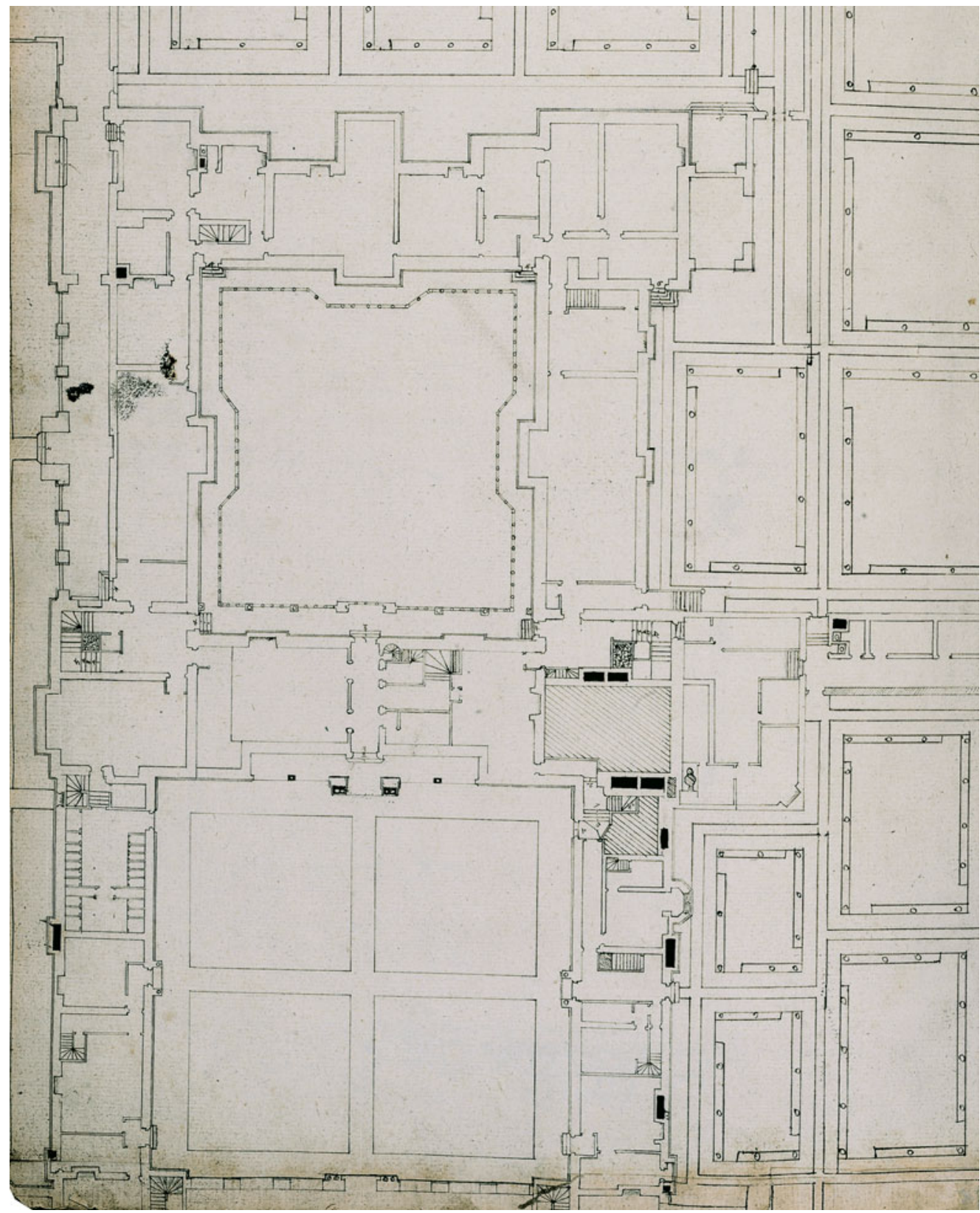

Fig. 1. John Thorpe's ground-floor plan of Theobalds, c. 1606 (courtesy of the Trustees of Sir John Soane's Museum): north to right. The Middle Court is shown below and the Conduit Court above. Some of the planted grids of the Prioy Garden (north) and Maze Garden (west) are included in the drawing. 


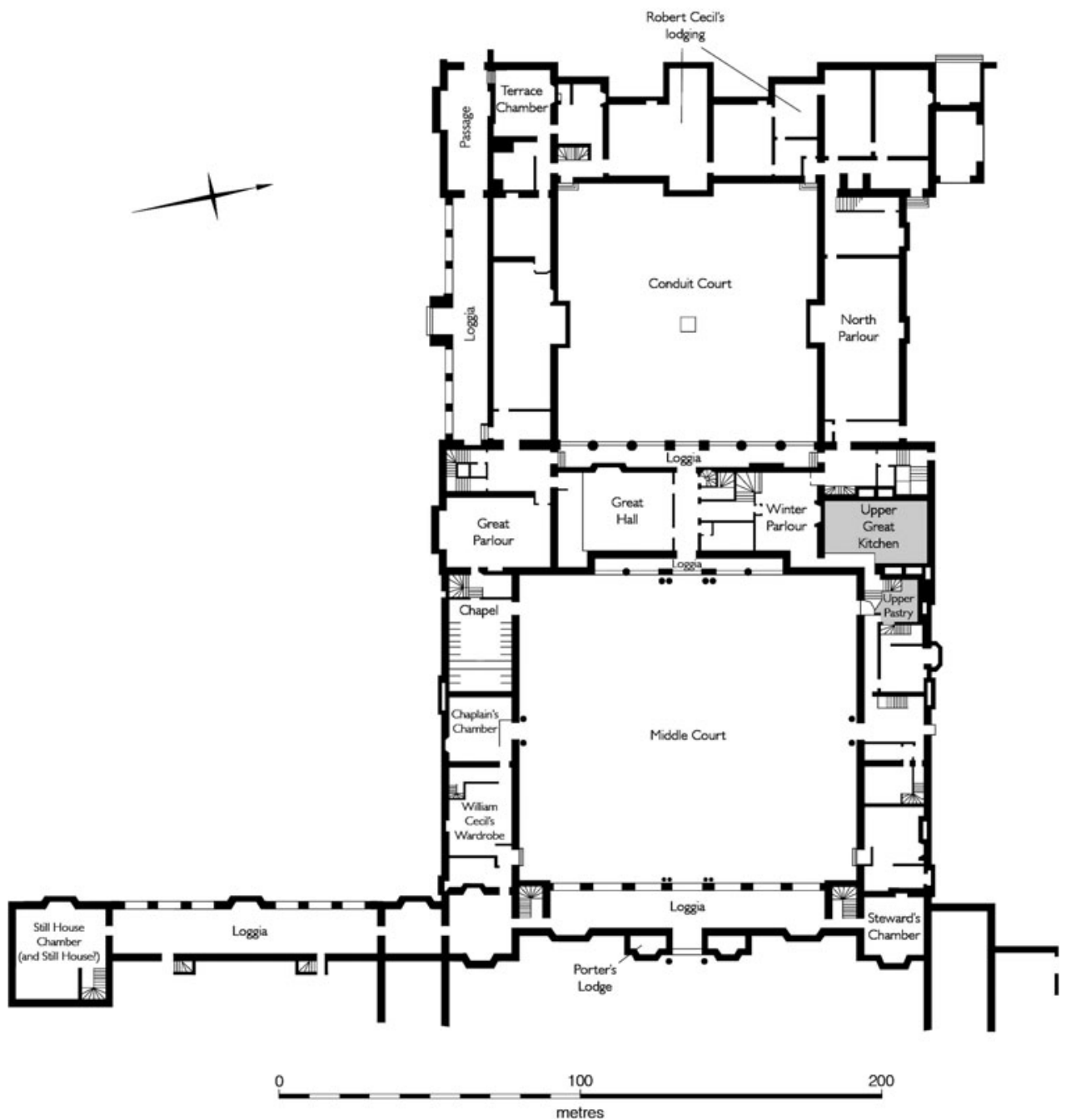

Fig. 2. Reconstruction plan of the ground floor of Theobalds, based on the survey by John Thorpe (C) Historic England, Philip Sinton). In this and the other reconstruction plans, only the house's two main courtyards are shown, along with the projecting range at the south-east 


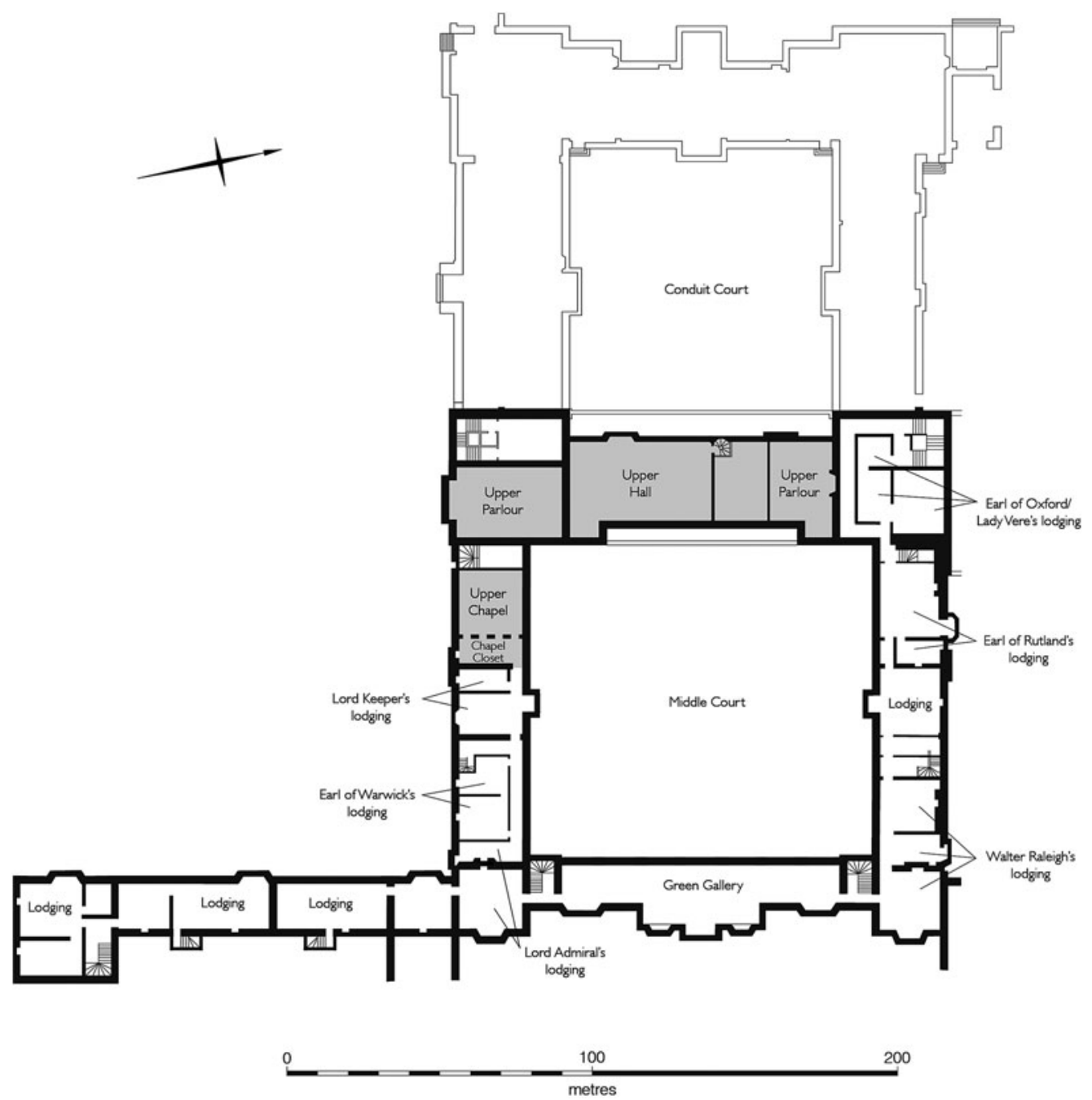

Fig. 3. Conjectural reconstruction plan of the first floor of the Middle Court of Theobalds (@) Historic England, Philip Sinton) 


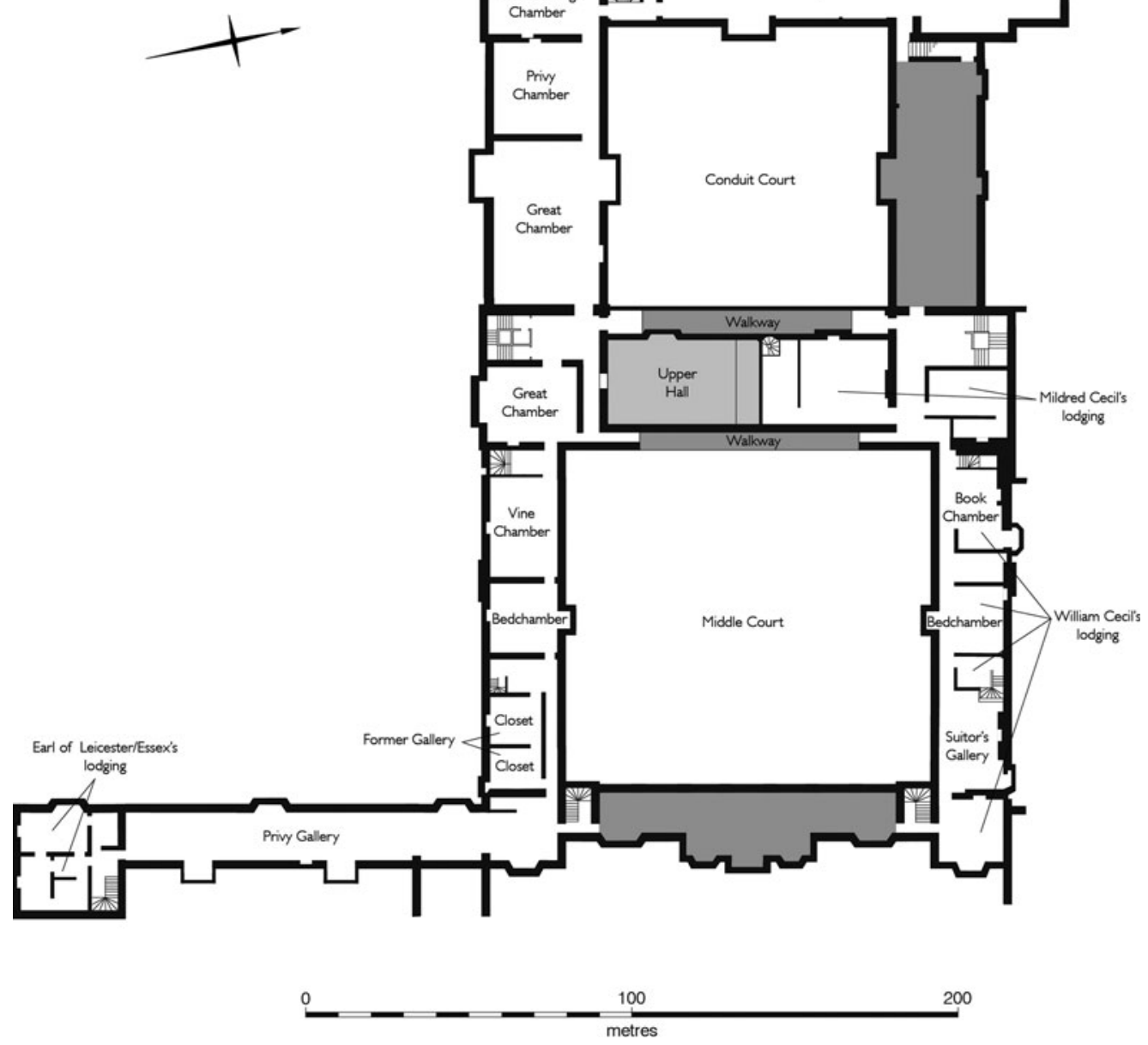

Fig. 4. Conjectural reconstruction plan of the first floor of the Conduit Court and the second floor of the Middle Court of Theobalds (ㄷ Historic England, Philip Sinton). The areas shaded in dark grey represent leaded walks 


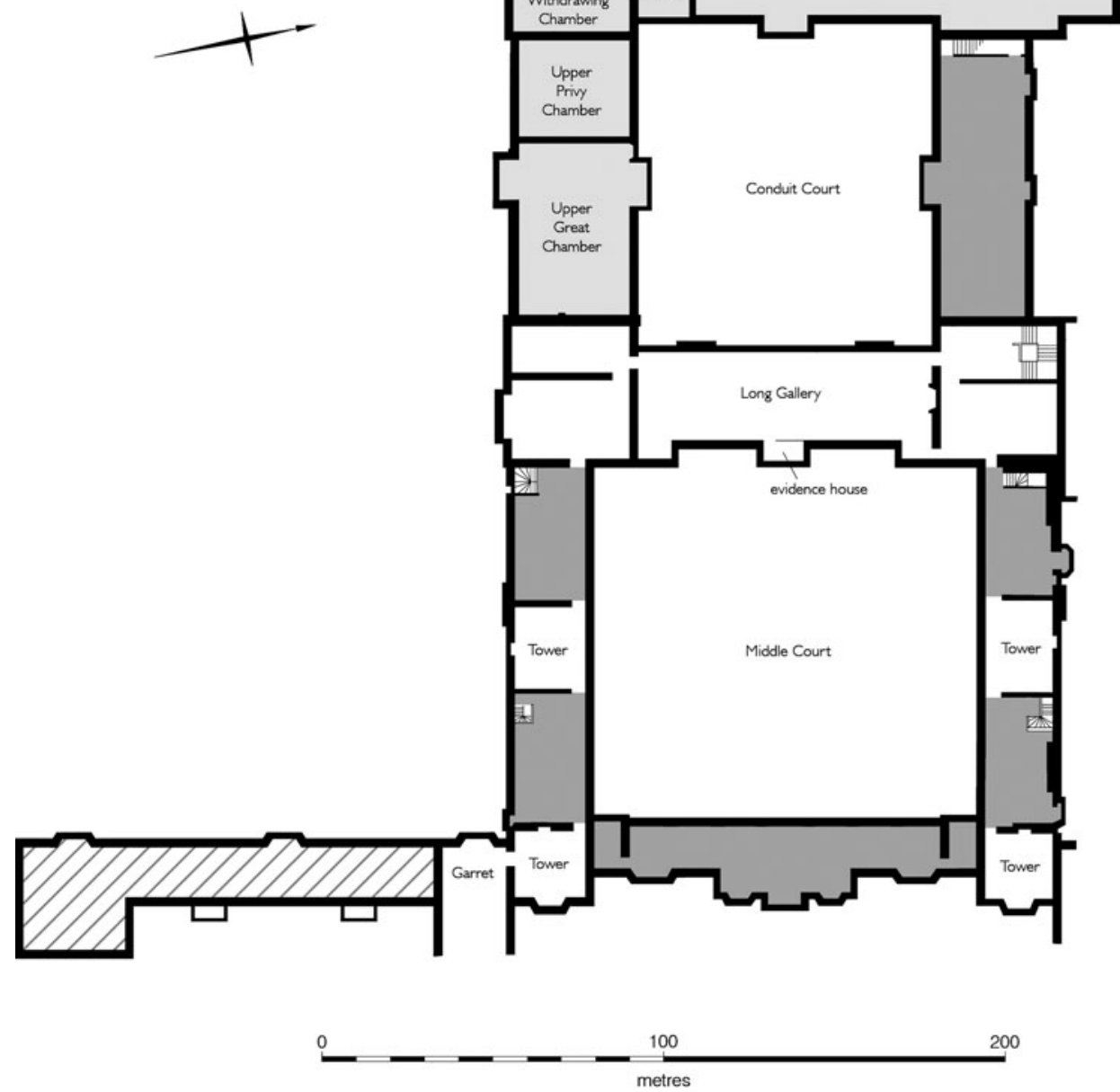

Fig. 5. Conjectural reconstruction plan of the attic/tower floor of the Middle Court of Theobalds (C) Historic England, Philip Sinton). The darker shading represents roofs that formed leaded walks, though that on the east of the Middle Court was at a lower (second-floor) level and that on the north of the Conduit Court was at first-floor level. The roof of the projecting gallery range appears to have been pitched and tiled 


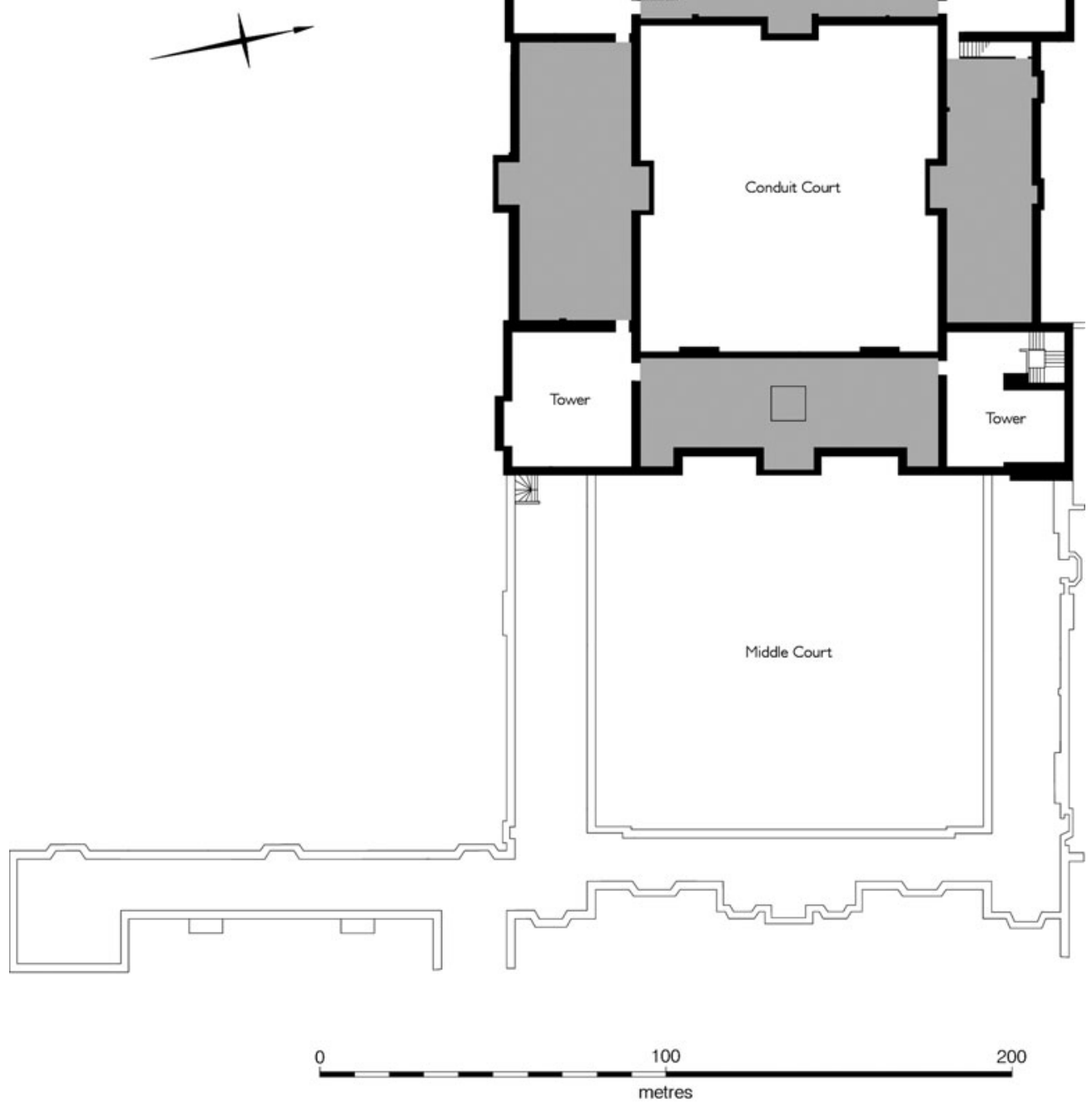

Fig. 6. Conjectural reconstruction plan of the attic/tower floor of the Conduit Court of Theobalds (@) Historic England, Philip Sinton). The shading represents roofs that formed leaded walks, though that on the north was at a lower (first-floor) level 


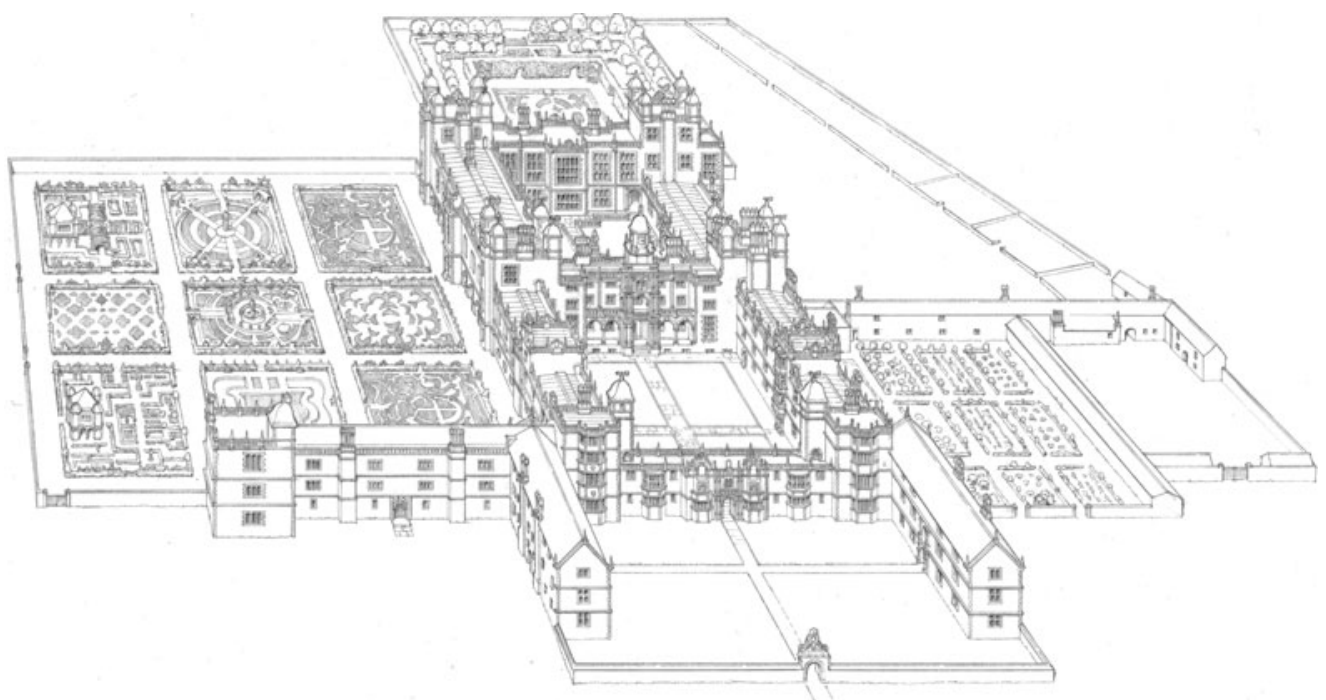

Fig. 7. Conjectural reconstruction of the exterior of Theobalds, viewed from the south-east, showing the principal courtyards, projecting gallery range, Base Court and some of the gardens

(C) Historic England, Allan Adams)

Theobalds is notable as a house that was designed, in particular, to reflect the tastes and requirements of the itinerant monarch and royal court. ${ }^{17}$ At home and abroad, the house was known to people who moved in the highest circles, a number of whom visited it and recorded their impressions. It was host to Queen Elizabeth in at least eleven different years, making it her most visited house outside the royal palaces. ${ }^{18}$ It later proved as popular with James I. The king appears to have made a total of nine visits before 22 May 1607, when Theobalds became royal property. ${ }^{19}$ Especially notable was James's visit of 24-28 July 1606, when he was accompanied by his brother-in-law, King Christian IV of Denmark, and members of the Danish royal court. From 1607 onwards, King James spent a large amount of time at Theobalds, as did his son Charles. No wonder that, despite the house's 'verrie good repaire', the parliamentarians chose to demolish the building, which for three generations had stood as a prominent symbol of the power of royalty and the wealth and influence of the English elite. ${ }^{20}$

\section{SUMMARY OF THE HOUSE'S HISTORY AND DEVELOPMENT}

Theobalds (also known as Thibaulds, Theballs, Tibols and Tybolles) was acquired in 1564 by Sir William Cecil, apparently with the intention of creating a future home for his younger son, Robert, born the preceding year. ${ }^{21}$ At that point, the estate included a moated manor house. This building, which Cecil seems to have upgraded by the 


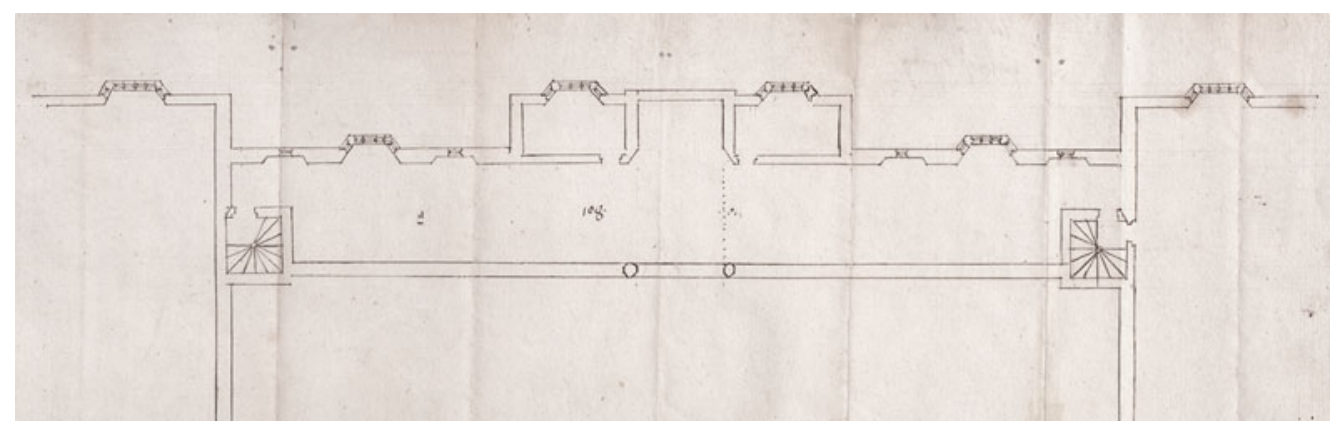

Fig. 8. Plan of the east (gatehouse) range of the Middle Court of Theobalds, c. 1570 (Hatfield House Archives, Cecil Papers 143/48; courtesy of the Marquess of Salisbury): north to left. The drawing probably represents the ground floor, but could also illustrate the first floor, and may not be as executed

addition of a parlour with a great chamber above, accommodated Queen Elizabeth on her visit of July 1564 .

Almost immediately, Cecil began to build a new house on a site three-quarters of a mile to the north-east. This seems initially to have included a single main courtyard, the site of which was later occupied by Theobalds's Conduit Court. Clearly, this house proved inadequate, and plans for expansion were probably in hand by 1566. A drawing endorsed by Cecil makes clear that a new second courtyard, to the east of the old court, was to be the point of entry, and that a hall was to be located in a new dividing range. The hall range had been initiated by 1567 and was completed in 1569-70, with a stone loggia and frontispiece on the east façade. We know this was executed by Hans Hendrik van Paesschen, a mason from Antwerp who built Sir Thomas Gresham's Royal Exchange (1566-70), the first major Renaissance-style building in the City of London. ${ }^{22}$

A plan that survives in the Thorpe collection in Sir John Soane's Museum is clearly a design for the new courtyard and it (or the drawing on which it is based) is likely to date from $c .1567 .{ }^{23}$ By $1568 / 69$, work was probably under way on the north, south and east ranges of this courtyard, which came to be known as the Middle Court or Inner Court (until the 1580s) and Second Court (from the 1580s). This phase of building must have been largely complete by September 1571, when Queen Elizabeth made her first known visit to the new Theobalds. Certainly, the north and south ranges were finished in time for the royal visit of July 1572, although the east range - which is documented in surviving designs (Figs 8 and 9) - was apparently only completed in 1573/74.

There appears to have been almost no let-up in the process of construction. Driven in part by his new status - Cecil was made first Baron Burghley in 1571 and Lord Treasurer in 1572 - and in part by the queen's favour of Theobalds, Cecil pushed ahead with a new round of work. This included the addition of a projecting gallery range, to the south-east of the Middle Court, a design for which survives (Fig. 10). This three-storey range seems to have been completed in $1573 / 74$ and was in full use for the royal visit of $1577 \cdot{ }^{24}$

Meanwhile, Lord Burghley began to rebuild the 'old' courtyard on the west. This appears to have been something of a labour of love, taking over ten years to complete 


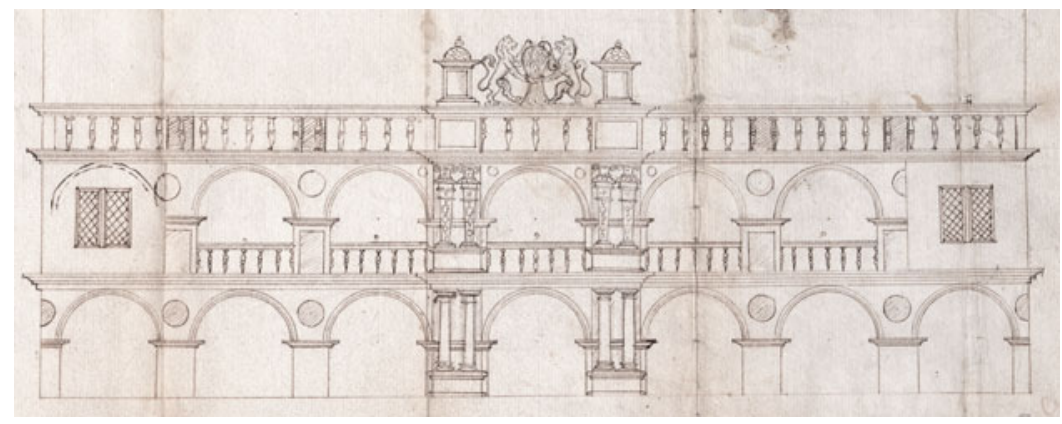

Fig. 9. Design for the courtyard façade of the east (gatehouse) range of the Middle Court, possibly in the hand of Lord Burghley, c. 1570 (HHA, CP 143/50; courtesy of the Marquess of Salisbury). The façade was altered in execution; for instance, there were only three balconies at first-floor level in the range as completed

and resulting in Theobalds's most extravagant interiors. Notably, a design for the rebuilding of this courtyard - known as the Conduit or Fountain Court - survives, dated 1572, in the hand of Henry Hawthorne. ${ }^{25}$ Hawthorne was an employee of the Royal Works who seems to have served as Lord Burghley's architect until at least 1577, when his position was taken over by another royal officer, John Symons. Although a later plan by John Thorpe (see Fig. 1) shows that the courtyard was altered in execution, the original vision - that is, of a square court with corner pavilions or towers - endured throughout the design process.

Construction of the Conduit Court was probably begun later in 1572 and was well under way by September 1575. Two years after, payments were made to workmen including a glazier, painter and plasterer ${ }^{26}$ The three new ranges around the courtyard seem to have been structurally complete by 1578 , when chimneys were made and glass with 'diverse armes' installed. ${ }^{27}$ The ranges were fitted out over the next few years: the chimneypiece and glass were added to the new great chamber in 1582, the glass to the great staircase in the same year, and the north parlour was brought to final completion in $1585 .{ }^{28}$ Elizabeth I declared herself delighted with the work: on 2 June 1583, Roger Manners reported that she 'was never in any place better plesed, and sure the howse, garden and walks may compare with any delicat place in Itally'. ${ }^{29}$

The completion of the Conduit Court was the last substantial work undertaken at Theobalds by Lord Burghley. Indeed, it was the last substantial work undertaken in the house's history. Following his father's death in August 1598, Sir Robert Cecil (1563-1612) made a number of changes to the house (discussed below), but these seem to have been comparatively minor in nature. It is possible to be more categorical about the alterations carried out after 1607, since detailed accounts of the Royal Works survive. Over these years, various changes were made, but the integrity of the Elizabethan house remained. Thus, the house recorded in such detail in the parliamentary survey of 1650 is largely the Theobalds completed by Lord Burghley in the 1580 . 


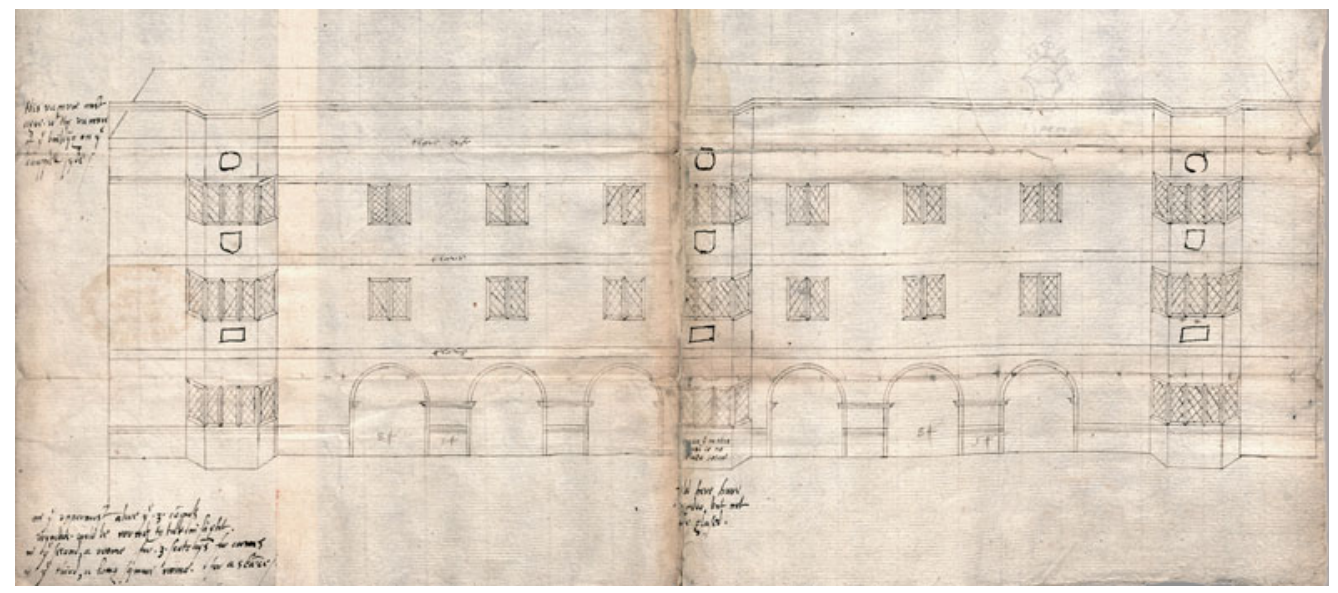

Fig. 10. Design for the west façade of the projecting gallery range, probably in the hand of Lord Burghley, c. 1572 (HHA, CP 143/41-42; courtesy of the Marquess of Salisbury)

THEOBALDS UNDER SIR WILLIAM CECIL, LORD BURGHLEY (1564-98)

As has been outlined, there were two key stages in the architectural development of Theobalds: the building of the Middle Court and projecting gallery range (c. 1567-74), and the rebuilding of the Conduit Court (c. 1572-85). Before the completion of the Conduit Court, Theobalds was already fully functional, with the wide range of rooms and lodgings expected of a house of its status. The addition of the Conduit Court extended the house's accommodation to levels usually associated with royal palaces. The plan of these two courtyards will now be explored.

\section{MIDDLE COURT}

Having gained access to the Middle Court via the gatehouse on its east side, visitors to Theobalds in the mid-1570s would have found themselves in an area $110 \mathrm{ft}(33.5 \mathrm{~m})$ square (see Figs 1, 2 and 7). ${ }^{30}$ Aside from the eastern gatehouse range - which was of two storeys with a flat roof - the courtyard ranges rose through three main storeys. In the north and south ranges, the levels must have been relatively low, especially on the ground and first floors, since they were matched in height by the two main levels of the hall range to the west. The roofs of all three ranges were, like that of the eastern block, flat with leaded walks. At the four corners of the Middle Court there were towers, while there were additional turrets at the centres of the two side ranges. At the courtyard's south-east corner, a narrow range projected into the Great Garden. This was also of three storeys, and seemingly had a tower at its southern end.

The east façade of the hall range featured an elaborate stone frontispiece, which formed a five-bay loggia at ground-floor level. On either side of the loggia were bay windows, lighting the upper end of the hall and the winter parlour respectively. 


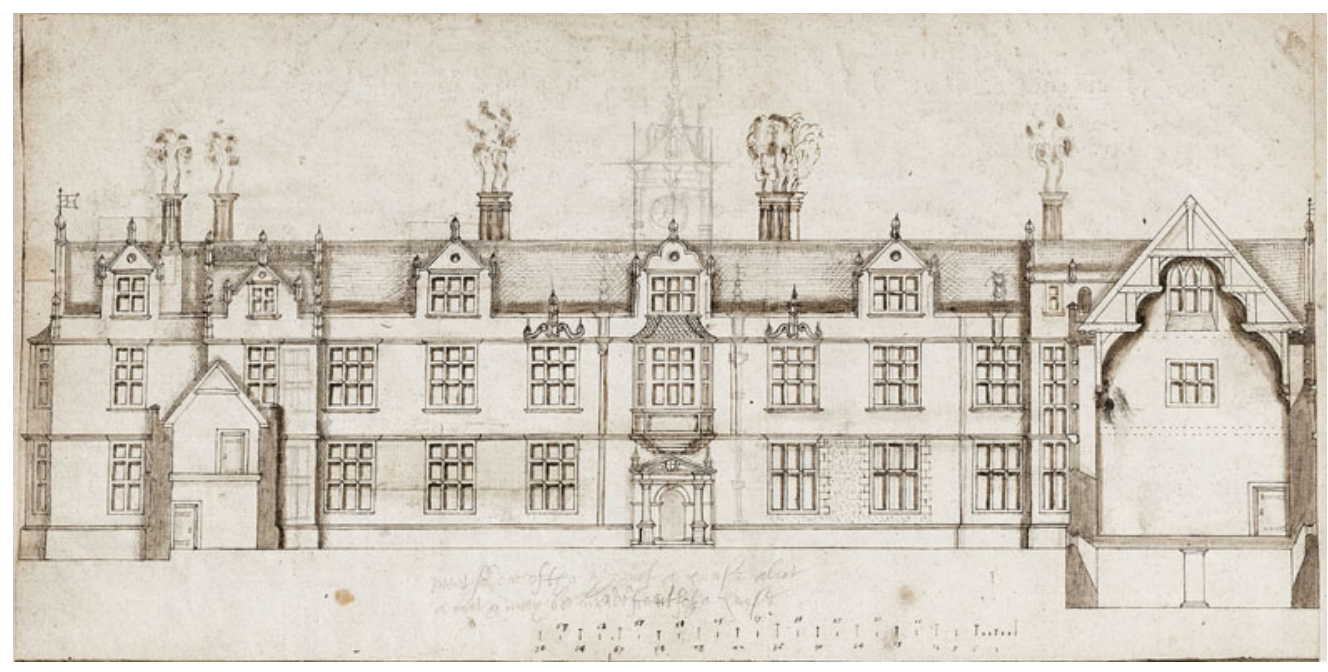

Fig. 11. Drawing by John Thorpe of an unnamed house, identified as being a design for the courtyard façade of the south (state) range of Theobalds's Middle Court (courtesy of the Trustees of Sir John Soane's Museum). It is probably a copy by Thorpe of an original design dating from c. 1567. The design was altered in execution

At upper-floor level, the frontispiece formed an external walkway, which gave access to an arch containing 'verrie manie faire curious paintinges and gildinges of pictures [probably carvings], whereof two are called the pictures of Peace and Warre' ${ }^{31}$ Above, the range's roof was flat, serving as an additional walkway. ${ }^{32}$ At its centre was a timber lantern 'of excellent workemanshipp curiouslie wrought', containing a chiming clock. ${ }^{33}$

Facing the hall, on the inside of the gatehouse range, was another loggia, this one of seven bays, with turret staircases at each end. The wall on the loggia's east side contained windows overlooking the Dial or Base Court - the first of Theobalds's main courtyards, forming the approach to the house. In projecting bays either side of the gateway were two rooms, that on the south serving as the porter's lodge (see Fig. 8). ${ }^{34}$ Above was a long gallery, with windows opening on to balconies (see Fig. 9).

Importantly, when it comes to the courtyard façade of the south range, a design appears to survive (Fig. 11). This drawing, included in Thorpe's book and associated with a contemporary plan, was identified by Summerson as being related to Theobalds. ${ }^{35}$ It certainly conforms with much that is known about the house. For instance, the cross-section on the right seems to show the great hall with cellar below, while that on the left represents the intersection of the south range with the lower gatehouse block. At the centre of the range is a columned doorway with a bay window above; such a doorway is shown in this position on Thorpe's ground-floor plan (see Fig. 1).

In certain other respects, however, the design was clearly altered in execution: a floor level was added above the great hall, and the roofs of all the courtyard's ranges were flat 
rather than pitched. The form of the windows may have changed also: the lawyer Roger Wilbraham, who visited Theobalds in 1599, reported of the Middle Court: 'the windowes beneth but one light, those above 2 lightes without transome, and compassed at the top'. ${ }^{36}$ Compass windows were bay windows usually having a semi-circular profile. The earliest, securely dateable, extant example is that on the north front of Burghley House, which is dated 1587 , so those at Theobalds must have been an innovation. ${ }^{37}$ Although Wilbraham's description may relate to the range's garden front, it seems certain that the drawing in Thorpe's book must represent an early proposal, perhaps of $c$. 1567. It is the only evidence we have as to the possible appearance of the courtyard's state range - and also the range to the north, presumably designed in a matching style.

\section{GROUND FLOOR}

The principal entrance to Theobalds's interior was via the arch at the centre of the loggia of the hall range. According to the parliamentary survey, lead pipes fed two cisterns in 'two peeces' of this arch, probably basins on either side. ${ }^{38}$ As is known from Thorpe's ground plan (see Fig. 1), the door led directly into the screen passage, with the great hall on the south and the Conduit Court on the west. The survey records that - like most of the 'polite' rooms at Theobalds - the hall's walls were wainscotted, and its screen was timber, bearing a dial and coat of arms (undoubtedly those of Cecil); this was topped by a minstrels' gallery or 'clockloft'. ${ }^{39}$ In medieval tradition, the hall was high, rising through the equivalent of ground, first and second floors of the Middle Court. It had an oriel window at its south-east and from its upper end was overlooked by an opening, set in a 'wainscott case wrought and carved', accessible from the great staircase (see Fig. 11). ${ }^{40}$ The room was paved and had a chimneypiece of blue marble. An account shows that in 1585 'Jenings' was paid 'to tryck out England on ye Hall wall in whyt and black' and 'to mak ye fram for ye chart of England'. ${ }^{41}$ 'Tricking' was a method of indicating the tinctures (or colours) in a coat of arms by the use of abbreviations or symbols, so Jenings - if not a painter himself - was perhaps preparing the heraldic decoration for the painter and ensuring it was accurate.

According to the survey, the hall boasted an elaborate roof, 'arrched over at the top with curved timber of curious workemanshipp'. ${ }^{42}$ As there was a long gallery above the hall (see below), this cannot have been a timber roof of standard design and construction, like that shown in the drawing of c. 1567 (see Fig. 11). The timberwork can only have been decorative, positioned beneath a flat ceiling. The result must have been something like the great hall at Longleat in Wiltshire (as reworked in the early 1570s) and the slightly later great hall at Wollaton Hall in Nottinghamshire (Fig. 12), both of which have non-structural hammerbeam trusses with a chamber above (the 'Prospect Room' in the case of Wollaton). ${ }^{43}$

At the low end of the hall, beyond the screen passage, were the pantry and buttery, with the usual triple door arrangement, but most of the service rooms were at basement level, the great kitchen and pastry rising up through the ground floor also (see Fig. 2). This left space for a winter parlour, which by 1650 was known as the 'King's waiters' 


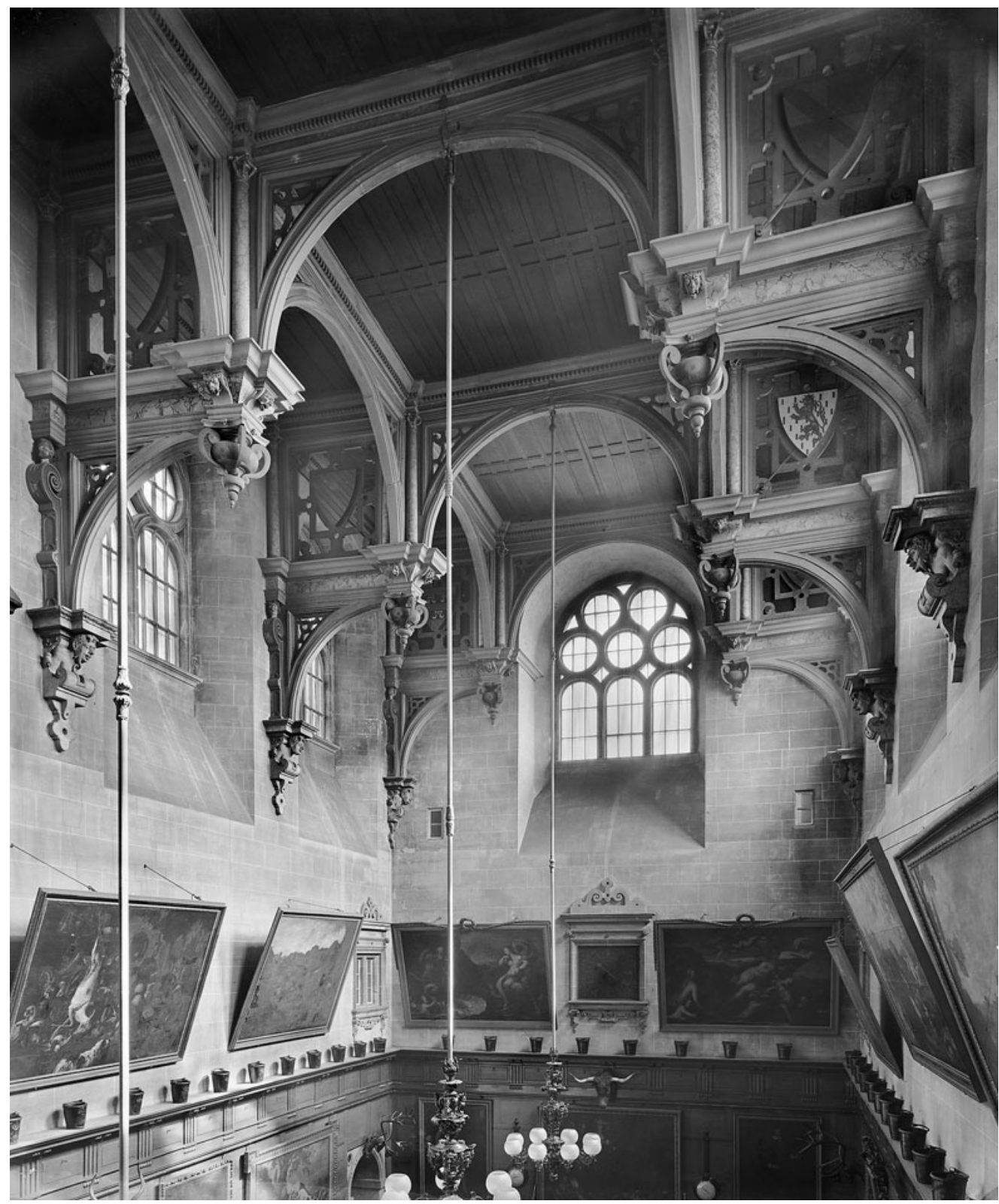

Fig. 12. The roof of the great hall at Wollaton Hall, Nottinghamshire (built 1580-88; @ Country Life). The hammerbeam trusses are decorative rather than structural, as there is another chamber (the 'Prospect Room') above the hall. The roof may have been influenced by that of the great hall at Theobalds 
chamber'; it contained a chimneypiece of grey Sussex marble, with an overmantel bearing a coat of arms (presumably those of Cecil). ${ }^{44}$ Seemingly, the room was equal in height to the ground and first floors of the Middle Court's side ranges, and it had a large bay window, looking east. Here, the Cecils would have dined and entertained on an informal basis, and the schedule of accommodation for the royal visit of 1572 confirms that the room was to be used for the 'Lord Treasurer's table' - that is, as Burghley's dining chamber. ${ }^{45}$

The winter parlour was situated close to the 'north stairs', which rose in a parallel position to the great stairs on the south. Thorpe's plan shows that these two staircases were of similar arrangement, with quarter landings (see Fig. 1). The north stairs led to the Cecils' second-floor lodgings and the long gallery over the hall, as well as to the lead walk on the west side of the hall and the walk on top of the hall range, which - after 1585 - provided access to the leads of the Conduit Court.

On the south, adjacent to the great staircase, was the great parlour. This had a bay window overlooking the Great Garden and, like the winter parlour, seems to have risen through the equivalent of two storeys of the Middle Court. Used as the queen's waiters' room by 1650, the parlour featured a chimneypiece 'cut into Antickes and other wilde beasts', with jambs of blue marble. ${ }^{46}$ Schedules of accommodation show that, during Queen Elizabeth's visits, the room was used as her presence chamber (for receptions and audiences), with the great hall serving as great or guard chamber. ${ }^{47}$ Beneath was a colonnaded wine cellar, apparently a space of some grandeur. ${ }^{48}$

The great parlour was linked to the chapel, positioned at the west end of the south range and also accessible directly from the Middle Court (see Figs 1 and 2). The chapel's east end was placed beneath an upper closet, the point of division being marked by a 'good faire lettis wainscott' screen. ${ }^{49}$ According to the parliamentary survey, its walls were 'full of scripture verses, callenders and direccons for morning and evening prayer, Monthes of the yeare Degrees of Marriage the Raigne of the kinges of England and the like', while the windows were painted. Box pews were arranged 'college-style', separated by a central aisle. ${ }^{50}$

The remainder of the ground floor of Theobalds's south range was accessed directly from the courtyard. To the east of the chapel were two good-sized rooms with a back staircase between them, leading to the first-floor lodgings and state apartment above. The room next to the chapel was the chaplain's chamber, ${ }^{51}$ while the chamber to the east, beyond the back stair, housed Lord Burghley's wardrobe and, on at least one royal visit, the Queen's Robes. ${ }^{52}$ The room at the east end of the south range was also used for the Queen's Robes during visits; this had a bay window and was associated with an inner closet. ${ }^{53}$

In the comparable position at the east end of the north range - also with a bay window was the steward's chamber, used during royal visits as the plate house. ${ }^{54}$ The function of the other rooms on the ground floor of the north range is not clear, since they were not named or allocated in schedules of accommodation. Thorpe's plan (see Fig. 1) shows that the area included at least three fair-sized chambers, one having a bay window overlooking the Privy Garden. Given their proximity to service rooms - including the pastry and privy kitchen - it is likely that these served as the lodgings or workrooms of upper members of Burghley's household. 
FIRST FLOOR

As has been stated, the major rooms of the hall range seem to have risen through ground- and first-floor levels. Meanwhile, on both south and north sides of the Middle Court, the first floors comprised lodgings intended for the Cecils' relatives, friends and guests. In reconstructing the layouts of these rooms, the schedules of accommodation are invaluable.

On the north, there were four sets of lodgings (see Fig. 3). In the early seventeenth century, almost certainly in altered form, they served as the apartment of the Prince of Wales. This was probably because they were associated with the Green Gallery on the south-east, a long gallery being considered a highly desirable component of any state apartment by the Jacobean period, especially in a royal palace. ${ }^{55}$ Each lodging a term usually used to describe a bedchamber and pallet chamber - was accessible via a separate staircase, as was conventional for the time. That at the west seems to have been situated adjacent to the north stairs, above the great kitchen. It was occupied during the 1572 royal visit by Edward de Vere (1550-1604), seventeenth Earl of Oxford, Burghley's ward and the husband of his eldest daughter, Anne (1556-88). The main room was also known as 'the La of Oxfordes Chamber' and Lady Vere's Chamber or Nursery, reflecting its use by Elizabeth de Vere (1575-1627), born at Theobalds and brought up by her grandparents. ${ }^{56}$

To the east, beneath the rooms of Lord Burghley, was a lodging used by - and named after - Edward Manners (1549-87), third Earl of Rutland, another of Burghley's wards. ${ }^{57}$ Beyond this was a lodging described as being 'over ye pve kytene', which occupied the east half of the range at basement level. ${ }^{58}$ Finally, to the east of this, was a comparatively large lodging - comprising a chamber, inner chamber and pallet chamber - which seems to have enjoyed access to the Green Gallery on the south-east. This lodging was occupied by Lord Burghley himself during the royal visit of 1572 , when his own rooms were given over to the queen. In 1591, it was used by Sir Walter Raleigh (1554-1618). ${ }^{59}$

The equivalent lodgings in the south range were higher in status; they overlooked the Great Garden and lay beneath the state apartment. However, they were smaller in extent, since the west part of the range contained the upper chapel and chapel closet. Adjacent to this closet was the first of three sets of lodgings. Located beneath Queen Elizabeth's bedchamber, it included a room known as the 'Lord Keeper's Chamber', so presumably it had at some point accommodated Burghley's brother-in-law, Sir Nicholas Bacon (1510-79). ${ }^{60}$ During royal visits, the room was used by the queen's attendants, and it was still the 'Maide of Honors chamber' in $1650 .{ }^{61} \mathrm{~A}$ staircase in this general area is shown on Thorpe's ground plan (see Fig. 1), and this would have connected the lodging to the state apartment above.

On the immediate east was a chamber which took its name from Ambrose Dudley (c. 1530-90), third Earl of Warwick, a royal official and brother of the Earl of Leicester. Warwick was married to one of Queen Elizabeth's most favoured attendants, Anne (1548/9-1604), née Russell, and other intimate royal aides occupied the room in later years. Finally, the lodging at the east end of the south range - with a bay window overlooking the Dial Court - was known as the 'Lord Admiral's Chamber' by at least 1572, 
taking its name from Edward Clinton (1512-85), first Earl of Lincoln. ${ }^{62}$ As with Lord Warwick, Lincoln was married to an aide of the queen, Elizabeth (1527-90), née FitzGerald.

From $c .1574$, this area of the house was associated with the first-floor lodgings in the projecting gallery range. These were three in number, and were similarly intended for guests of high status. They were each separately accessed by staircases on the east, adjacent to the Dovehouse Court. The lodging at the far end of the range - 'in a tower' - was the largest, with a chamber and two pallet chambers. ${ }^{63}$ In 1577 and 1583 , this was allocated to the queen's cousin Henry Carey (1526-96), first Baron Hunsdon, and in 1591 it was used as the dining room of Robert Devereux (1565-1601), second Earl of Essex, whose main rooms were on the floor above. ${ }^{64}$

Close to all these lodgings was the long gallery on the upper storey of the gatehouse range, accessible via stair turrets at each end of the loggia. The gallery was probably accessible from the first-floor lodgings to north and south, although there is no conclusive evidence of this. The room, completed in 1573/74, was known as 'ye paynted Gallory' or, by at least $1607-09$, as the Green Gallery. ${ }^{65}$ In the parliamentary survey of 1650, the room was described as being $109 \mathrm{ft}(33.2 \mathrm{~m})$ long and $12 \mathrm{ft}(3.7 \mathrm{~m})$ wide, with two freestone chimneypieces. The gallery had windows opening on to the Middle Court, with 'three Belconie doors', demonstrating that the surviving elevation drawing was altered in execution (see Fig. 9). On the east side were further windows opening on to 'two small stone Belconies'. 66 These formed part of the central section of the gallery, which jutted out towards the Dial Court (see Figs 3 and 8).

The earliest known detailed description of the Green Gallery's interior is that of Jacob Rathgeb, secretary to the Duke of Wirtemberg, who visited Theobalds in 1592. He recalled a 'hall' containing depictions of 'the kingdom of England, with all its cities, towns and villages, mountains and rivers; as also the armorial bearings and domains of every esquire, lord, knight, and noble who possesses lands and retains to whatever extent' ${ }^{67}$ Eight years later, Baron Waldstein stated that the room featured

the coats-of-arms of the earls and barons of England: all round the walls are trees painted in green, one tree for every county in England, and from their boughs hang the arms of those earls, barons, and nobles who live in that particular county. The specialities of any county are included ....68

Further information was supplied by Frederic Gerschow, secretary to the Duke of Stettin-Pomerania, who visited in 1602 and described the gallery as displaying 'all England, represented by 52 trees, each tree representing one province' ${ }^{69}$ In the parliamentary survey of 1650, the gallery was stated to have been 'latelie divided into fower lodginge Roomes, and two lobbies'; this probably happened after 1640, when Johann Albrecht de Mandelslo visited and described the room's decoration without noting any subdivision. ${ }^{70}$

First and foremost, the Green Gallery's interior reflected Lord Burghley's interest in pedigrees, which was in evidence throughout Theobalds. Burghley is likely to have been responsible for the gallery's scheme; a drawing by him, showing trees hung with empty shields for coats of arms and banners bearing the names of various Cecils, must give an impression of the finished result (Fig. 13). As well as coats of arms, however, it is clear that the scheme included geographical and cartographic information, 


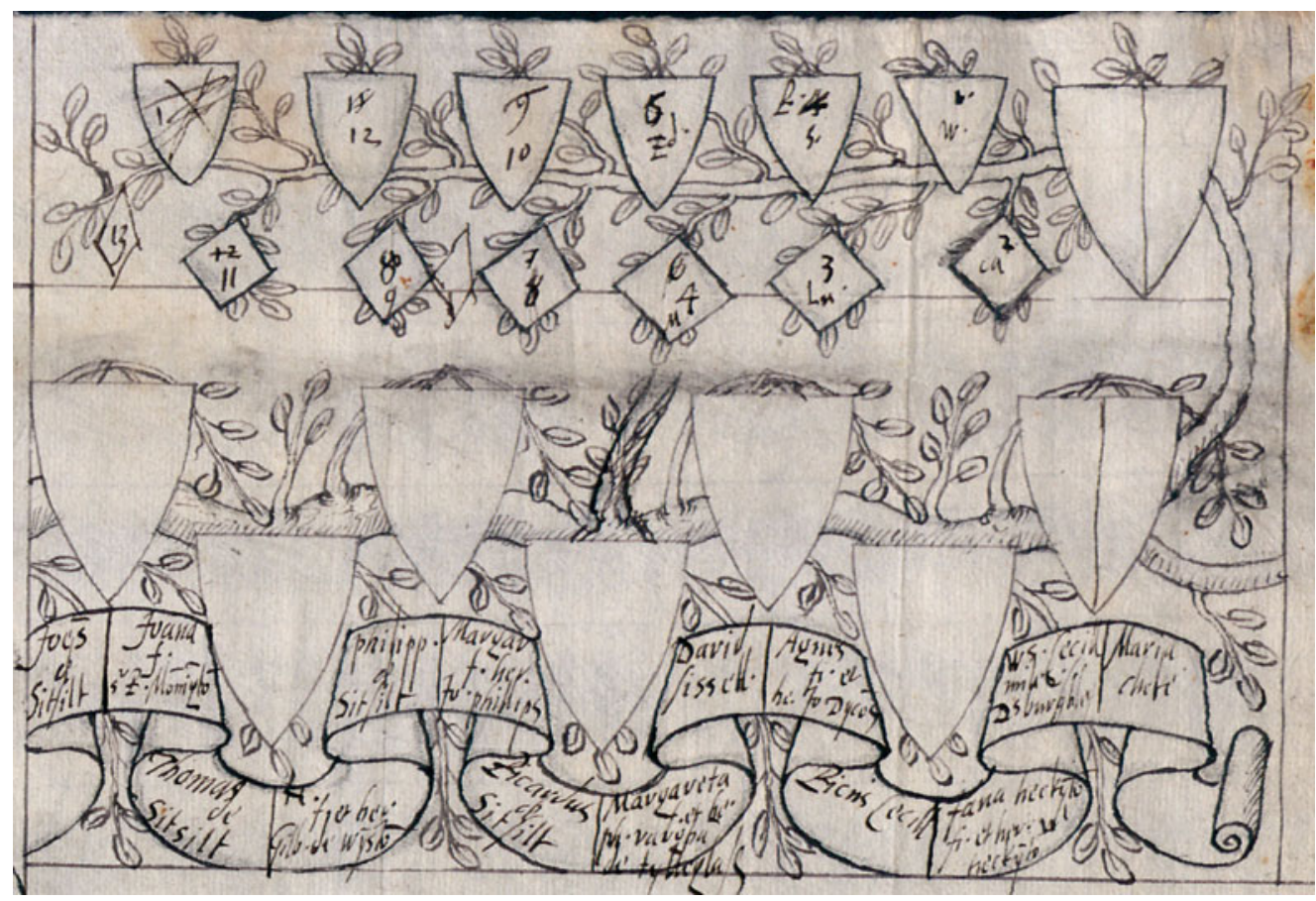

Fig. 13. Detail of a drawing by Lord Burghley showing the genealogy of the Cecils depicted on shields and banners hung on branches (HHA, CP 143/12-13; courtesy of the Marquess of Salisbury). The drawing may give an impression of the interior decoration of the Green Gallery at Theobalds

another area in which Burghley was interested and involved. He was apparently an active supporter of Christopher Saxton, who carried out the first cartographic survey of England and Wales, producing a series of thirty-four maps engraved between 1574 and 1578. A collection of early proofs of Saxton's maps - with Burghley's annotations survives, bound up with other maps as his own personal atlas of England and Wales (Fig. 14).

The contemporaneity between Saxton's survey and the decoration of the Green Gallery is notable, the survey of England having been completed by March $1574 \cdot{ }^{71}$ Thus, the gallery's decorative scheme would have been innovative - drawing upon the first accurate maps of the country - and of great interest and use to Burghley, his peers and the queen herself. It also served to represent the greatness of England and Wales, an appropriate theme given that the gallery seems to have served as a 'show room' for visitors.

SECOND FLOOR, ATTICS AND TOWERS

In the Middle Court at Theobalds, as at great houses such as Hampton Court (1514-29), status was expressed vertically: the most important rooms on both the south and north sides were at the highest (second-floor) level. The house's first, and - until the 1580s - 


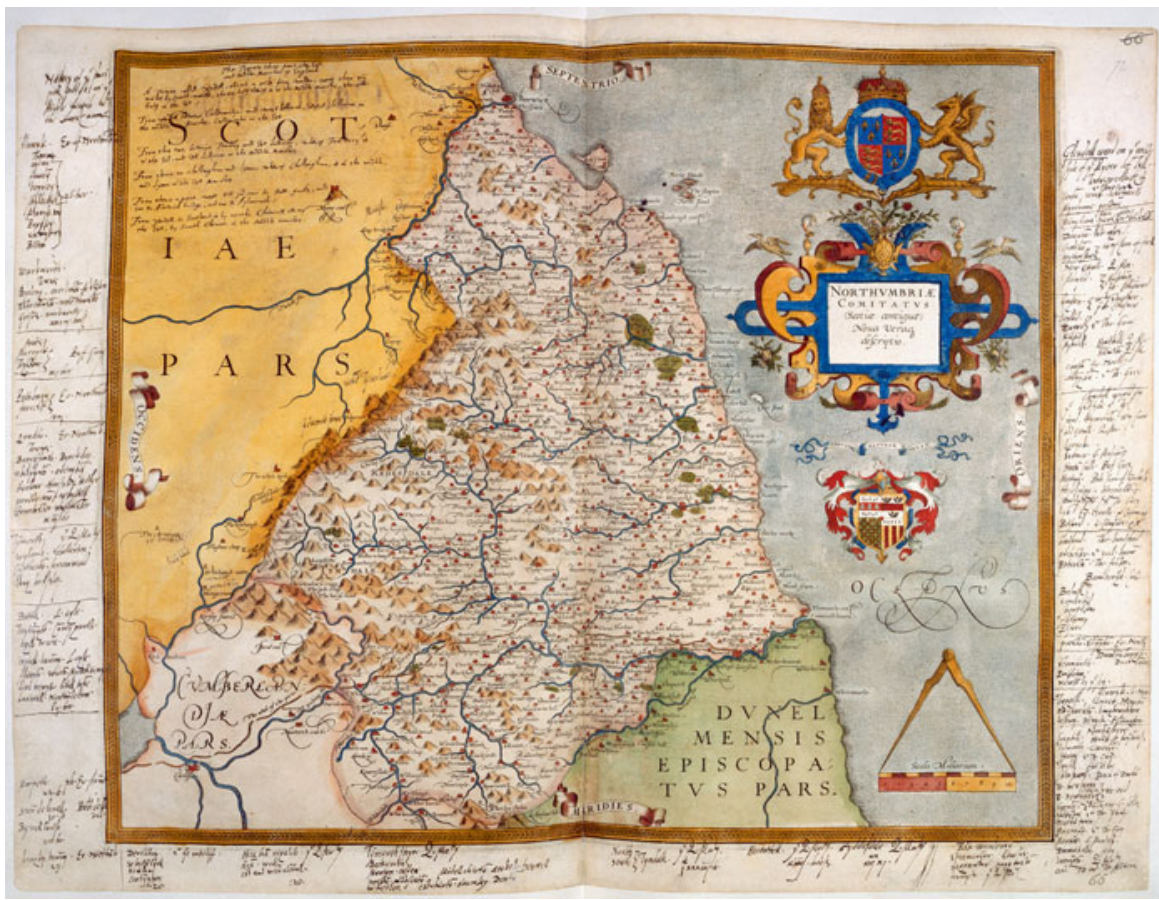

Fig. 14. Christopher Saxton's map of Northumberland, as published in 1579, with annotations by Lord Burghley, from Burghley's personal atlas (BL Royal 18 D. III, ff. 710-72;

(C) The British Library Board)

only, state apartment was on the south, running eastwards from the top of the great staircase (see Fig. 4). The convenience and success of the apartment is proven by the fact that it continued to be used by Queen Elizabeth even after the completion of the much grander suite in the Conduit Court. ${ }^{72}$ One of the advantages of this earlier suite may have been its height, and therefore its distance: for Elizabeth, comparative inaccessibility was an advantage, and it also aided tight security.

The first room of the suite was the great or dining chamber, later known as the queen's presence chamber. This was clearly used by Lord Burghley as his own great chamber, while during royal visits the room became Queen Elizabeth's privy chamber, used for her private dining. ${ }^{73}$ According to the parliamentary survey, the great chamber was wainscotted, 'floored with spruce deale boordes, of a good scent', and had a large window overlooking the Great Garden. Its stone chimneypiece was 'excellentlie well carved', and featured a device, in that it bore a black marble bowl fed with water. ${ }^{74}$

Adjoining the great chamber on the north was a lobby, this containing an open wainscot case 'wrought and carved to looke downe into ye hall' ${ }^{75}$ Another lobby, on the chamber's east, contained a staircase leading down to the chapel. Additionally, the great chamber seems to have had a doorway providing access to the walkway in the hall's frontispiece and from there to the Cecils' lodgings in the north range. 
On the east, the state apartment continued with a withdrawing chamber, known in Elizabethan times as the 'vyne' or 'vine chamber' - presumably on account of its decoration. During the house's time as a royal palace, it came to be known as the privy chamber. ${ }^{76}$ Positioned above the chapel, it had a carved chimneypiece with a wainscot overmantel. Beyond, at the centre of the south range, was the queen's bedchamber. Contemporary references make clear that this room was positioned beneath a turret, which gave it external emphasis. ${ }^{77}$ The parliamentary survey records that it was part lined with hangings and part panelled, with a border of wainscot 'cutt curioslie, and coullered', with gilded edges. Served by a stool house, the chamber had 'fair windows' and a stone chimneypiece with a timber overmantel featuring four pilasters. ${ }^{78}$ The royal arms was added in the early 16oos, though the overmantel may have featured Queen Elizabeth's arms even before this time. Visiting Theobalds in 1599, Roger Wilbraham found 'in the $\mathrm{Q}^{\mathrm{s}}$ chamber written over the chymney, Semper Adamas [always firm]' - probably a mistake for Semper Eadem (always the same), which was Elizabeth I's personal motto. ${ }^{79}$

When it came to the area on the east of the queen's bedchamber, there were two phases of construction. In the first phase - from the completion of the south range in c. 1572 until that of the projecting range in c. 1574 - this area contained a gallery, mentioned in the schedule of accommodation of $1572 .{ }^{80}$ The fact that it was a key part of the original design is implied by the apparent symmetry of the plan of the Middle Court: in the north range, as shall be seen, Lord Burghley's second-floor suite included a gallery in the corresponding position. ${ }^{81}$ Once the gallery had been superseded by the Privy Gallery in 1574 (discussed below), the space beyond the queen's bedchamber was reworked. The schedules of 1577, 1583 and 1591 show that this area included two chambers. ${ }^{82}$ These were allocated to the queen's gentlewomen during royal visits, and functioned as closets - one large and heated, the other small and utilitarian. From this part of the suite a door led towards the roof walk over the Green Gallery. ${ }^{83}$ Seemingly in this area, too, was the 'Queenes pages roome', which was connected to the back staircase. ${ }^{84}$

By 1650, this inner accommodation appears to have been expanded, for the survey also includes the 'Queen's Coffer Chamber', which featured a wainscot overmantel 'well painted and gilded'. 85 This was probably positioned at the east end of the range, with a bay window looking east (see Fig. 4). A sizeable room in this position is not mentioned in any of the Elizabethan schedules of accommodation - a notable omission - and so it is probable that this area was originally occupied by the north end of the Privy Gallery. ${ }^{86}$ It could have been partly separated off as a lobby, like those later included at each end of the first-floor long gallery at Hatfield House. At Theobalds, the area must have been subsequently divided off to form a completely separate chamber, perhaps in $c .1605-06$.

Additionally, the inner area of the state apartment was associated with rooms in the towers (see Fig. 5). The queen's back staircase led to the leads of the south range and the lodging in the tower at the south-east of the court, which had a 'faire large window looking eastward'. ${ }^{87}$ The staircase seems also to have formed the principal access to the room in the tower above the queen's bedchamber, a position of importance. ${ }^{88}$ 
In $c .1572-74$, Theobalds's state apartment was extended by the addition of a long gallery. The provision of this space clearly constituted the raison d'être for the construction of the three-storeyed projecting range (see Fig. 10), and it seems that this feature of the Theobalds layout proved immensely influential in reinforcing a fashion for the building of spacious long galleries in association with state apartments. Earlier country houses that included state apartments with long galleries were Hampton Court (c. 1514-16) and Ingatestone Hall in Essex (c. 1540-45), but they were by no means common in the first half of the sixteenth century. That situation changed after the mid-1570s: almost all later Elizabethan and Jacobean country houses of significant size and pretension featured long galleries, including Holdenby, Kirby Hall (c. 1575-84) and Wollaton Hall. ${ }^{89}$ The natural conclusion is that Cecil's work at Theobalds was a catalyst, being innovative in both this and other respects.

Initially, Burghley had provided a relatively modest gallery in the south range. Now, he made up for any error of judgement by building a grand gallery, which was known as the Queen's Gallery by 1583 and retained this name until 1650, ${ }^{90}$ although it was also known as the Privy Gallery. ${ }^{91}$ According to the parliamentary survey, the room was $14 \mathrm{ft}(4.3 \mathrm{~m})$ wide and $109 \mathrm{ft}(33.2 \mathrm{~m})$ long - the same length as the Green Gallery. ${ }^{92} \mathrm{It}$ had an 'arch seelinge' - seemingly a barrel-vault, like that in the long gallery at Chastleton House in Oxfordshire (1607-12; Fig. 15). ${ }^{93}$ The room's walls were panelled and 'well painted', the chimneypiece was of freestone, while (judging by the surviving elevation drawing) there were bay windows on the room's west side, overlooking the Great Garden. There may also have been bay windows on the room's east, in the upper levels of the two staircase turrets. Opening off the gallery was a stool house, while the room's northern end contained a door leading to the lead walk over the Green Gallery. ${ }^{94}$

Other descriptions of the Privy Gallery appear to survive, a fact that has not been acknowledged before. Frederic Gerschow, a visitor of 1602, was probably referring to this room when he described a gallery containing 'the coats-of-arms of all the noble families of England, 20 in number, also all the viscounts and barons, about 42, the labores of Herculis, and the game called billiards, on a long cloth-covered table' ${ }^{95}$ Another to refer to the Privy Gallery was Johann Albrecht de Mandelslo, a visitor of 1640. He recorded that the gallery contained portraits 'en grand' of Queen Elizabeth, several other queens of England, and a group of Protestant leaders - John Frederick (1503-54), Elector of Saxony, Admiral Chatillon (1519-72), Cardinal Chatillon (1517-71), and their brother Francois de Coligny d'Andelot (1521-69) - as well as portraits of the Turkish emperors and 'les travaux d'Hercule en sept tableaux' ${ }^{96}$

In a tower at the south end of the Privy Gallery was a lodging clearly intended to be used by someone associated with the occupant of the state apartment. ${ }^{97}$ Given this intimate connection, it is fascinating to find that the lodging was used successively by Queen Elizabeth's two most notable favourites - firstly, in 1577 and 1583, by Robert Dudley (1532/3-88), first Earl of Leicester, and in 1591 by Leicester's godson, Robert Devereux, the Earl of Essex. ${ }^{98}$ According to schedules of accommodation, the lodging comprised a chamber with two pallet chambers, though the parliamentary survey seems to refer to three chambers, with three associated lobbies. One of these chambers featured a freestone chimneypiece, carved and gilded, with a timber 


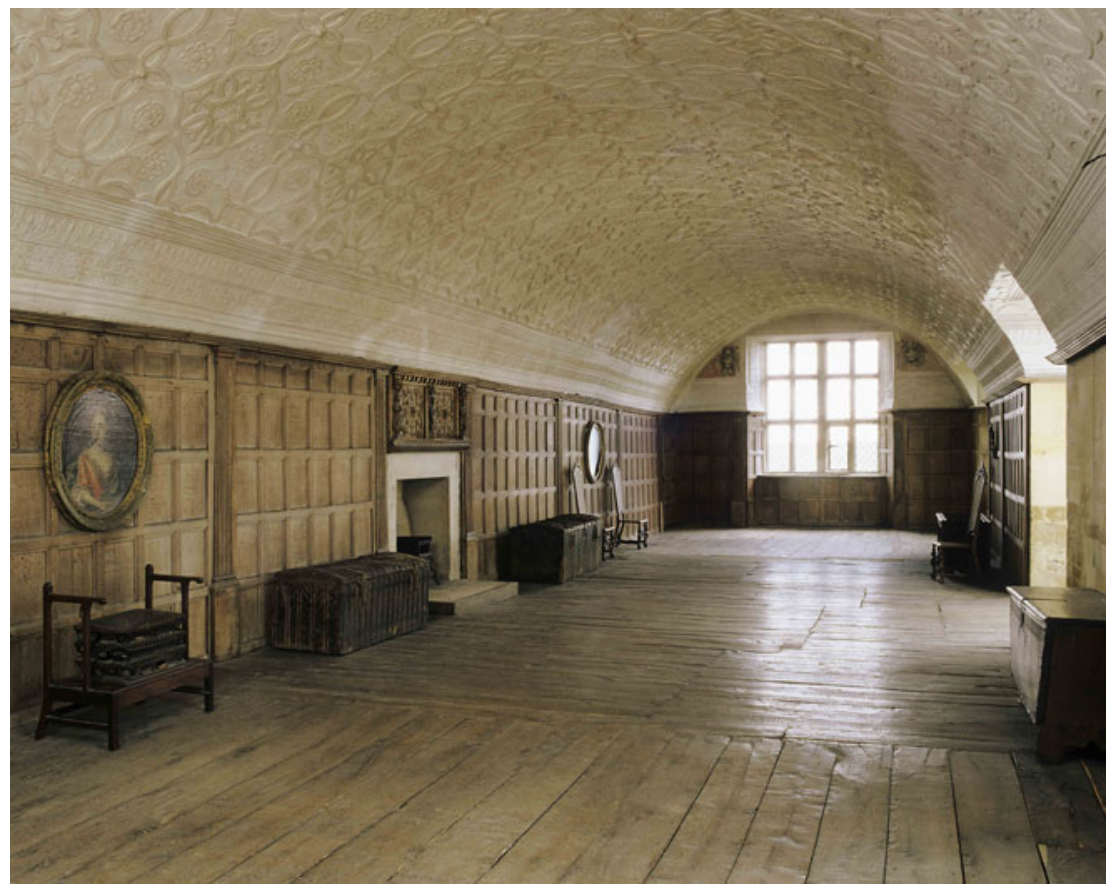

Fig. 15. The interior of the barrel-vaulted long gallery at Chastleton House, Oxfordshire, built in 1607-12 (@ National Trust Images/Nadia Mackenzie). It may have been influenced by the barrel-vaulted Privy Gallery at Theobalds, built in the 1570 s

overmantel 'painted with pictures and covered green and gilt with gold'. 99 Another was referred to as the 'corner chamber' and had windows looking south and west into the Great Garden, with a 'fair chimneypiece of stone, with a rich painting over

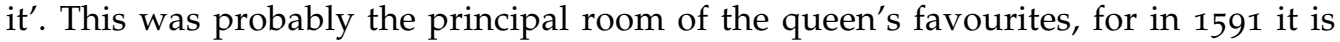
clear that Essex was accommodated on the gallery's 'garden side'. ${ }^{100}$ Accounts of 1578 record the painting of 'my Lo of Lec Armes over the chymne', 101 and this is likely to refer to the 'corner chamber'; the painting probably served to commemorate the earl's stay of May 1577. A staircase here led to the ground-floor Still House Chamber (used by Leicester's servants during his stays), the loggia and the garden, as well as to the first-floor lodgings; in 1591, the southernmost of these provided a dining room for Essex, thereby expanding his suite. ${ }^{102}$

Another gallery, the long gallery above the great hall, was apparently accessible from the queen's rooms, although it did not form part of the state or any other apartment (see Fig. 5). This is likely to have been created in the phase of work of $c$. 1567-70, and seems to have represented a change from the initial design. The gallery occupied a slightly higher level than that of the state apartment, although it was probably not as high as the rooms in the tower at the south end of the hall range (see Fig. 6). This lodging in the 'great tower' or 'Earles Towre' seems to have been traditionally allocated to the Lord 
Chamberlain, and may be identified with the 'King's Secretary's Chamber', plus closet and inner chamber, referred to in the survey of $1650 .{ }^{103}$

Probably, both gallery and tower lodging were accessed via the newel staircase which rose between the queen's great and withdrawing chambers, though the gallery was seemingly also accessible from the north staircase. ${ }^{104}$ Almost certainly, it was this gallery that Baron Waldstein referred to in 1600 when writing that 'Upon the roof of the house there is a splendid gallery from which you can see the Tower of London'. ${ }^{105}$ The room contained 'a closett vawted with stone for evidences'. ${ }^{106}$ This was an evidence house, a secure place for the storage of documents and other valuables, and it may have been located in the upper part of the stone frontispiece on the gallery's east side. Beyond this, nothing is known about the gallery's arrangement and decoration: by 1650 , it had been subdivided into ' 12 verrie small rooms'. ${ }^{107}$ Nor is anything known about the rooms at the south and north ends of the gallery, positioned above the great chamber and Lady Burghley's lodgings respectively. It is likely, however, that those on the south comprised the chamber, pallet chamber and two 'Chaplannes chambers' listed in the survey, while those on the north may have included the lodging of the Lord Chamberlain; ${ }^{108}$ the latter seems to have been used earlier (in 1572) by Sir Christopher Hatton (see below).

As well as offering fine views, the gallery above the hall would have provided a route of passage between the state apartment and the lodgings of Lord and Lady Burghley. These were at second-floor level in the north range, running parallel with the queen's rooms (see Fig. 4). The composition of Lord Burghley's lodging can be set out with a fair degree of confidence. At the centre of the north range was his bedchamber, with an associated pallet chamber. Like the queen's bedchamber, Burghley's bedchamber was topped by a turret containing a room, this serving as Burghley's evidence house. ${ }^{109}$ To the east of his bedchamber was a room, listed but unallocated in the schedules of accommodation, which may have served as a withdrawing chamber.

Beyond were the 'suitor's gallery' and an inner room, shaped 'lyke a squyer' ${ }^{110}$ As with Burghley's bedchamber, his gallery - no doubt named after the crowd which followed him wherever he went - found its parallel in the state apartment on the south, at least as planned before $c .1574 \cdot{ }^{111}$ In 1577 and 1583 , the Suitor's Gallery and square room were used for 'the Lord Treasurer's hall' or 'table' - that is, they functioned as Burghley's great chamber, while his own great chamber in the south range was used by the queen. ${ }^{112}$ During the royal visit of 1591, the square room served 'for the council chamber'. ${ }^{113}$ Its remote location must have been seen as an advantage, and the room had direct access to the roof walk over the Green Gallery. In addition, the schedules of accommodation for 1591 make clear that Lord Burghley's suite included a 'book chamber' or library which seems to have been positioned at the west end of the range. ${ }^{114}$

Next to the north staircase were the rooms of Mildred Cecil (1526-89), Lady Burghley: 'two lodgings', 'terninge Southward towards the hall'. ${ }^{115}$ These placed the lady of the house at the heart of its daily working, with ready access to service rooms, rooms of reception and entertainment, and the first-floor lodgings where the Cecils' relatives were accommodated. Also associated with Lady Burghley's suite was the 'towre lodging chamb' at the north end of the hall range, close to the rooftop long gallery 
(see Fig. 5); during the royal visit of 1572 , this was used by Sir Christopher Hatton. ${ }^{116}$ Since this constitutes the only surviving reference to the lodging (and the north-west tower) in the Elizabethan period, it is likely to have served a private, family use during royal visits. Possibly, it was the lodging of the Cecils' eldest son, Thomas (1542-1623), or - before the completion of the Conduit Court - of Robert Cecil.

\section{THE CONDUIT COURT}

The accommodation of Theobalds was considerably expanded and upgraded in $c$. 157285 by the reworking of the west courtyard, variously known as the Conduit, Fountain, Inner or Third Court. This was $86 \mathrm{ft}(26.2 \mathrm{~m})$ square, with blue-slate-covered towers at its four corners, each of which carried four turrets and housed four chambers (see Fig. 7). ${ }^{117}$ The existing hall range formed the courtyard's east side, and there were new - or heavily remodelled - blocks on the other three sides. The range on the north was a single storey in height, with a flat roof. This allowed for a lead walk, joining the hall and west ranges, and gave the state rooms on the south an open prospect northwards. The ranges on the south and west of the Conduit Court were of two storeys with flat roofs. The height of the first floor seems to have been greater than that of the Middle Court, with the rooms at this storey probably being almost level with the latter's second-floor rooms (see Fig. 4). The west side of the hall block was fronted with a loggia of seven arches, with a lead walk above.

Accessed from the north staircase, the walk on top of the hall range formed the beginning of a circuit, continuing with the flat roofs of the Conduit Court's south and west ranges (see Fig. 6). ${ }^{118}$ The result must have provided extraordinary views, and it was probably this area that was described by Baron Waldstein as 'an Astronomers' Walk on the roof-top'. ${ }^{119}$ The leads and walkways also had a different role, providing flexible arrangements for the use and access of the house. These external routes meant, for instance, that it was possible to move from the new state apartment to the family rooms without the need to traverse the great hall. ${ }^{120}$

At the centre of the Conduit Court stood a fountain, which gave the new court its name. This was made of black and white marble, and featured figures of Venus and Cupid, two 'greate stone boles' for water, and a 'figure of an old man' on the top. ${ }^{121}$ The use of black and white marble was carried into the interiors of the new state rooms, and must have made a very striking impression.

\section{GROUND FLOOR}

As Thorpe's plan of $c .1606$ shows (see Fig. 1), the north range was dominated by a single room - the north parlour, which was, by 1650 , in use as the royal Council Chamber. ${ }^{122}$ The parliamentary survey provides the only known detailed record of this 'very faire Roome', which had a bay window overlooking the courtyard. The parlour was floored with wood and 'pavements of Divers Coulleurs', while its walls were lined with wainscot. It had a carved freestone chimneypiece and, like the new great chamber on the south, had windows featuring coats of arms. ${ }^{123}$ At the parlour's east end was a small inner or withdrawing chamber, which was later used 'for the Clarkes 
of the privie Councell to wright in'. ${ }^{124}$ On the parlour's west was another withdrawing room, with an adjacent staircase; this provided access to the leads, the Great Gallery and the lodgings in the north-west tower.

The north parlour served as a grand space for daily dining and entertainment for the Cecil family. ${ }^{125}$ In particular, though, it must have been used by Robert Cecil, for whom the estate of Theobalds had apparently been acquired. It seems that Theobalds was formally settled on Robert by an indenture of 16 June 1587, and it has been said that he took possession of the house around spring 1589, Lord Burghley moving to Robert's house of Pymmes in nearby Edmonton. ${ }^{126}$ Certainly, increasingly prominent in the political and court arenas, Robert would have required lodgings of status. Knighted (at Theobalds) in 1591 and elevated to the Privy Council the same year, he was then appointed Secretary of State in 1596 and remained a significant figure under James I - he was created first Earl of Salisbury in 1605 and appointed Lord Treasurer in 1608. It is known that Theobalds contained a lodging allocated to the Earl of Salisbury by 1607-09 and, although its location is not mentioned, it is likely that this refers to the rooms on the ground floor of the Conduit Court's west range, which were named 'ye Lord of Salisburies Lodginges' in the survey of 1650 (see Fig. 2). ${ }^{127}$

Thus, the north parlour can be seen as the first room in Robert Cecil's great apartment, and there seems to have been a similar apartment on the south of the courtyard, perhaps intended for Robert's future wife - he married Elizabeth Brooke (1562-97) on 31 August 1589 - or a high-status visitor. While the suite on the south is likely to have continued into the south-west tower, that on the north was larger, extending into the western range, probably leaving the rooms in the north-west tower as a self-contained lodging. By 1650, the chambers in the west range included 'my Lord of Salisbury's Dining Room', an adjacent 'Retiring Room', another room adjoining a stool house, and 'Lord Salisbury's bedchamber'. ${ }^{128}$

The rooms in the tower at the north-west corner of the Conduit Court probably represent the 'double lodging' in which John Wolley (d. 1596), Secretary to Queen Elizabeth, was accommodated in $1591{ }^{129}$ It is notable, given his accommodation in this part of the house, that Wolley was a close colleague of Robert Cecil. Other friends and allies of Robert Cecil to be accommodated in this area during the royal visit of 1591 were John Stanhope (c. 1540-1621), Master of the Posts, and Sir George Carew (1555-1629), Master of the Ordnance in Ireland. ${ }^{130}$

At the south-west corner of the Conduit Court, under the state bedchamber, were rooms occupied during the royal visit of 1591 by William Brooke (1527-97), tenth Baron Cobham. ${ }^{131}$ He was perhaps Lord Burghley's oldest friend but - more relevant for his accommodation in this area - he was also, from 1589, Robert Cecil's father-inlaw. This lodging comprised four rooms and was adjacent to the terrace on the south side of the house. It may have been the same lodging of four rooms named in the parliamentary survey as the chambers of the 'Marquis of Hambleton', probably a reference to James (1606-49), third Marquess of Hamilton, a favourite of James I and Charles I. According to the survey, the lodging included a bedchamber, with a door leading to the Great Garden, and a dining room, looking north. ${ }^{132}$ The survey shows that there were three rooms on the east of this lodging, allocated by 1650 to Henry Rich 
(1590-1649), first Earl of Holland, one of James I's intimates. ${ }^{133}$ Thorpe's ground plan of c. 1606 (see Fig. 1) does not show a sufficient number of rooms in this area, so it is probable that the large chamber which stood beneath the great chamber was subdivided at some point after 1607 .

On the outer side of the south range, facing the Great Garden, there was a loggia. This had seven arches and its walls were 'painted with the kinges and queenes of England, and the pedigrees of the old lord Burley's and divers other antient families, with paintinges of many castles and battailes'. ${ }^{134}$ The loggia was accessible from beyond the foot of the great staircase, and therefore served to link house and garden. Visitors to describe this loggia were Paul Hentzner, who came to Theobalds in 1598, and Baron Waldstein, who visited two years later and mentioned a 'gallery' featuring 'portraits of the Cecil family, with an account of the notable acts of each under different reigns'. ${ }^{135}$ In 1640, Mandelslo described the loggia as including the arms of Cecil and his wife, 'who were descended from the ancient Kings of England'; above were statues of several English kings. ${ }^{136}$

Returning to the interior of the house from the loggia, a visitor would have encountered the great staircase. The great stair had been in this position since the completion of the hall range in 1570, providing access to the state apartment on the second floor of the Middle Court. It also had an adjacent flight descending to the basement, where rooms included wine cellars beneath the great parlour and the new south range. With the remodelling of the Conduit Court, the great staircase is likely to have been altered; it is certainly known that work was under way on the glazing of the stair's compartment in $1582 .{ }^{137}$

Lord Burghley's feelings about the need for grandeur in the ascent to state rooms have been recorded, and it is likely that the staircase at Theobalds was impressive and innovative. ${ }^{138}$ In 1650 , it was described as a 'verry faire halfe pace stairecase with carved posts, and with Lyons on the topps excellent well carved'. ${ }^{139}$ It was made up of thirty-two steps and, judging by Thorpe's plan (see Fig. 1), was of open-well construction. Thorpe seems to show a screen dividing the staircase from the lobby; this may have resembled that at Knole in Kent and may, as at that house, have been carried through to the stair's upper part. The survey makes clear that the staircase - named the 'Kinges Staires' - had five foot paces or landings, and it must therefore have risen twice round, through two floor levels. ${ }^{140}$ The stair hall bore a plaster ceiling, with 'gilded pendance hanginge Downe'. ${ }^{141}$ As Summerson noted, this staircase is believed to survive (though altered), having apparently been re-erected at Crews Hill House, Enfield, then at nearby Theobalds Park, and finally, in c. 1933, at Herstmonceux Castle, Sussex, where it remains today (Fig. 16). ${ }^{142}$

\section{FIRST FLOOR AND TOWERS}

From the 1580s, Theobalds's great staircase led to both the state apartment in the Middle Court and that in the Conduit Court (see Fig. 4). It also provided access to the leaded walk over the loggia on the west of the hall, which led to the north side of the house. Thus, it represented a crucial joining point. The first apartment to be encountered by a visitor would have been the state suite of the Conduit Court. This was made up of 


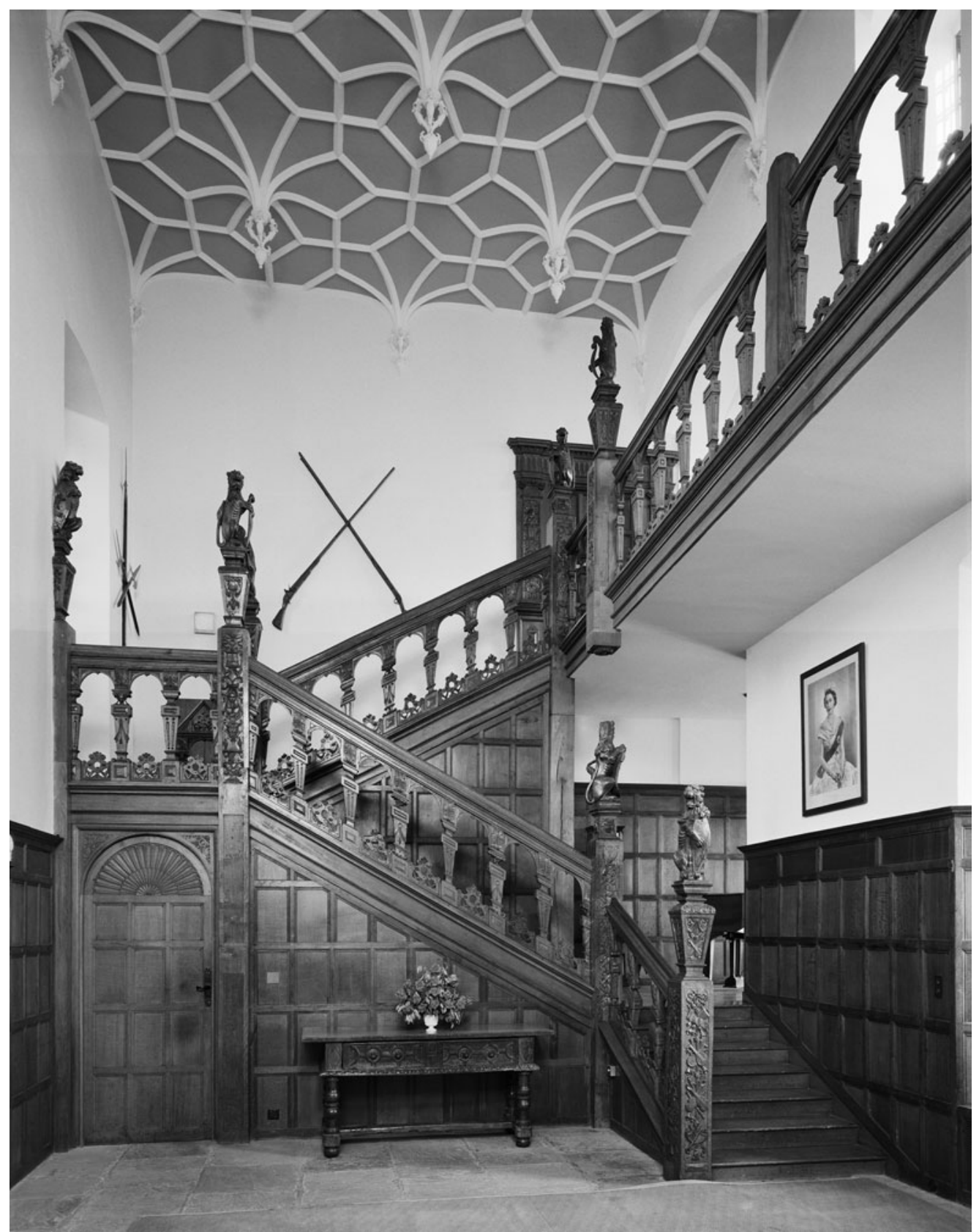

Fig. 16. The staircase at Herstmonceux Castle, East Sussex, said to have originally been the great staircase at Theobalds, probably created c. 1570 and altered in the early 1580 (C) Crown copyright: Historic England Archive). The stair was apparently moved to Herstmonceux from Enfield in c. 1933 
six main rooms and, in plan, was L-shaped. The most public room was the great chamber, known as the 'King's Presence Chamber' by 1650. ${ }^{143}$ In the sixteenth century, it would have been used - by Burghley and the queen - for dining in state, as well as receptions and entertainments. The interior of the great chamber is well documented, and constituted perhaps the most extraordinary decorative scheme at Theobalds. For Jacob Rathgeb, a visitor of 1592, the room was 'so ornamental and artistic that its equal is not easily to be met with'; its overall effect was 'right royal'. ${ }^{144}$

In 1585, Lord Burghley stated that the room had been created after the queen found fault 'with the smal mesure of her chamber', almost certainly the great chamber in the Middle Court. He wrote that the new room 'need not be envied of any for riches in it, more than the shew of old oaks, and such trees with painted leaves and fruit'. ${ }^{145}$ The earliest known description of the room - and a record that has been rarely cited to date - is given in an undated letter written by Charles Cavendish to his mother, Elizabeth, Countess of Shrewsbury. The letter can be confidently ascribed to July 1587, when Queen Elizabeth was staying at Theobalds. Cavendish, who was obviously one of the party, wrote that:

[Burghley's] great chamber I take to be lx foott long xxii brood and xxi hy wherin he hath mad at the nether end a fayre rock $w^{t}$ duckes fesantes $w^{t}$ divers other birdes $w^{\text {ch }}$ serves for a cubbord, the ould trees be thir still. he ... hath in the Rouff a sunne goinge $\mathrm{w}^{\mathrm{ch}}$ truly poynteth the hower and goeth the len[g]t[h] of the chamber, by nyght the moune and through the rouff $\mathrm{w}^{\text {ch }}$ be bordes paynted sky holes mad[e] lyghtes sett ther so the[y] appeare stares. ${ }^{146}$

Much of what Cavendish describes is confirmed by later accounts, including that by Rathgeb, who wrote in 1592:

On each side of the hall [great chamber] are six trees, having the natural bark so artfully joined, with birds' nests and leaves as well as fruit upon them, all managed in such a manner that you could not distinguish between the natural and these artificial trees. ${ }^{147}$

According to Baron Waldstein, these trees were columns, 'covered with the bark of trees, so that they do in fact look exactly like oaks and pines'. ${ }^{148}$ This decoration led to the room's Elizabethan title, the Arbour or Arbor - a name mentioned in contemporary documents but not hitherto acknowledged by historians. It was known as such by at least 1585 , and in 1591 was clearly referred to by this name as the first room in the queen's state apartment. ${ }^{149}$

Another feature of the great chamber, the 'fayre rock' or grotto, was under construction in 1584, and included sparkling quartz 'priors stones' from St. Vincent's Rock near Bristol. ${ }^{150}$ The grotto was described by Rathgeb as 'a very high rock, of all colours, made of real stones, out of which gushes a splendid fountain that falls into a large circular bowl or basin, supported by two savages'. ${ }^{151}$ Waldstein wrote of it as 'an overhanging rock or crag (here they call it a "grotto") made of different kinds of semi-transparent stone, and roofed over with pieces of coral, crystal, and all kinds of metallic ore'. He added that it was 'thatched with green grass, and inside can be seen a man and a woman dressed like wild men of the woods, and a number of animals creeping through the bushes'. ${ }^{152}$ At its base stood a bronze centaur. Clearly, the grotto was largely decorative, although the 
fountain may have been partly intended for the washing of hands after meals (a fountain also featured in the great chamber of the Middle Court).

Such an elaborate and curious 'device' must have delighted Elizabeth and her courtiers, but the great chamber's ceiling was even more extraordinary. In 1592, Rathgeb wrote of this in the following terms:

The ceiling or upper floor is very artistically constructed: it contains the twelve signs of the zodiac, so that at night you can see distinctly the stars proper to each; on the same stage the sun performs its course, which is without doubt contrived by some concealed ingenious mechanism. ${ }^{153}$

Cavendish's description (quoted above) gives further clues as to how this effect was achieved. It would seem that the ceiling was made of boards, painted like the sky and pierced with holes. Above these holes lights were set which, after dark, gave the impression of stars. The movement of the sun and moon - along the length of the chamber, around $60 \mathrm{ft}(18.3 \mathrm{~m})$ - must have been incredible indeed. No more is known about this ceiling, or who carried out the work. It seems certain, however, that its mechanism was set within a space above the boards, and that the great chamber did not, therefore, carry through the full height of the range.

Other features of the great chamber were a 'cloth of estatt mad of thin horne of divers colers' and, according to Baron Waldstein, two chimneypieces, one of alabaster and another 'in black and white marble'. ${ }^{154}$ The parliamentary survey refers only to the latter, which had ' 4 pilasters of the same stone wth the Queenes armes in the midst richlie gilt wth two Brasse Colomes of the figures of Vulcan \& Venus standinge before ye jammes of the chimney'. ${ }^{155}$ It was being made in $1581-82 .{ }^{156}$ The great chamber's windows included bays opening both north and south. According to the survey, these were set with 'severall Coates of Armes', which a visitor remarked belonged to 'the principal potentates of the world'. ${ }^{157}$ Following contemporary conventions in planning, it is likely that the west wall of the great chamber fell just beyond these bay windows.

According to the 1591 schedule of accommodation, the 'Queen's Arbour' was followed by another state room: the privy chamber, a name the room retained during Theobalds's years as a royal palace. ${ }^{158}$ In 1650 , the privy chamber was part wainscotted and part fitted for hangings, and contained a chimneypiece of black and white marble, with carved figures on each side and a 'faire frontispiece' of the same stone, carved and set above. ${ }^{159}$

By 1650, the privy chamber was followed by the 'withdrawinge Chamber', which had clearly existed for some time. ${ }^{160}$ Part of the room was fitted for hangings and the rest 'verrie fairely wainscotted'. ${ }^{161}$ This room is not mentioned in the 1591 schedule, and seems a strange omission given its importance and the comparative detail of the document. It is therefore possible that the withdrawing chamber was created by Sir Robert Cecil, as part of the alterations he undertook during the early seventeenth century. The creation of the room would have involved curtailing the earlier privy chamber and, possibly, state bedchamber, and the insertion of a wall with a chimneystack (see Fig. 4). The chimneypiece of the withdrawing chamber may be seen to offer support of this theory: in being made of 'richlie carved and gilded' freestone, with a timber 
overmantel, it broke the sequence of the others in the state apartment, which were of black and white marble. ${ }^{162}$

Dominating the south-west tower of Theobalds was the state bedchamber. This featured a chimneypiece of black and white marble, with three pilasters and 'carved works, wrought and sett above the same'. ${ }^{163}$ A 'great square window' overlooked the Great Garden, and there were 'twooe lesser windowes', looking west. ${ }^{164}$ The walls were part panelled 'with special worke', and the plastered ceiling was painted and gilded - it seems to have featured 120 'knobbes'. ${ }^{165}$ The 1591 schedule refers to a single pallet chamber (closet) in association with this bedchamber. ${ }^{166}$ This was presumably the room with a stone chimneypiece 'where the pages of the Backstaires weighted', and the survey also mentions an adjacent stool house. ${ }^{167}$ The back staircase - the lower part of which is shown in Thorpe's plan (see Fig. 1) - was referred to in the survey as the 'Gallerie Staires'. ${ }^{168}$ It led to the leaded walk and rooms in the south-west tower, as well as to the ground-floor lodgings and courtyard.

On the north of the state bedchamber and inner rooms was a long gallery. Known as the Great Gallery by at least 1587, and ascribed to the queen in $1591,{ }^{169}$ the gallery was entered via a 'faire wainscott portall, richlie carved' and measured $123 \mathrm{ft}(37.5 \mathrm{~m})$ long and $21 \mathrm{ft}$ (6.4) wide, making it the largest of Theobalds's long galleries. ${ }^{170}$ It had a plaster ceiling, featuring 'divers pendants roses and flower deluces, painted and guilded with gold'. ${ }^{171}$ It was almost certainly this ceiling that Jacob Rathgeb sketched in 1592 (Fig. 17). ${ }^{172}$ The gallery had three square lobbies in window bays, two of which would have been on the west side, overlooking the Maze Garden, with the other on the east. There were also other windows on both sides, 'makinge the roome verrie delightfull', as well as windows at the gallery's north end. ${ }^{173}$

A door at the north-west corner of the gallery opened on to a stone staircase of thirtytwo steps descending to the Maze Garden, while a door on the room's north-east led to the lead walk over the single-storey north range (see Fig. 4). Also in this area of the house was another staircase, 'on ye North corner of the buildinge over ye greate Gallerie'. ${ }^{174}$ This, shown in Thorpe's ground plan on the west of the north parlour, led to the leads and tower lodgings.

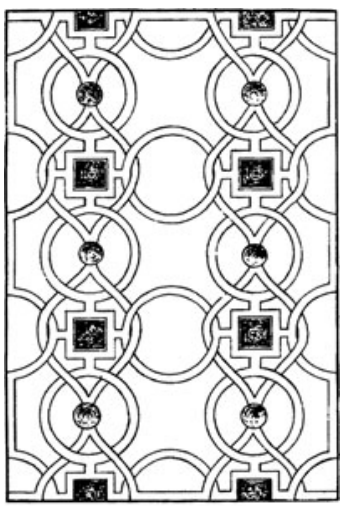

Fig. 17. Drawing by Jacob Rathgeb, secretary to the Duke of Wirtemberg, of a ceiling at Theobalds, 1592, as published in W.B. Rye's England as Seen by Foreigners in the Days of Elizabeth and James the First (1865). It is likely that it depicts the plaster ceiling in the Great Gallery, built in the 1580 s 
Adjoining the gallery, seemingly close to the stone staircase, was a wainscotted 'Lodginge Roome' with a chimneypiece. ${ }^{175}$ This is probably the room referred to by Mandelslo, a visitor of 1640, as 'a little cabinet panelled and painted' at the end of the gallery. ${ }^{176}$ It may also be the 'great passage room' mentioned in the Royal Works accounts of $1620-21 .{ }^{177}$ It is unclear what function this room was intended to have, but it was probably more a withdrawing chamber than a lodging, since it does not appear to have been associated with a closet.

It is possible that this area of Theobalds was depicted in a contemporary painting. The work dates from c. 1630-35 and shows an interior, with the figures of King Charles I, Queen Henrietta Maria, William Herbert, third Earl of Pembroke, his brother Philip Herbert, later fourth Earl of Pembroke - the brothers served successively as Lord Chamberlain - and the court dwarf Jeffrey Hudson (Fig. 18). There are also two painted copies of the work, as well as an engraving of $c$. 180o. The original painting and one of the copies are associated by tradition with Theobalds, the other copy being said to represent the palace of Whitehall. ${ }^{178}$

The link with Theobalds has, before now, not been interrogated, it being believed that there was insufficient information about the house's plan to reach a conclusion. ${ }^{179}$ The present study shows that the view - if it is indeed of Theobalds - can only be of the Great Gallery, which would be appropriate as this room formed part of King Charles's state apartment and was an area he is known to have made use of. ${ }^{180}$ Although the differences with what is known about the house are numerous, there are some elements that tie in. For instance, the staircase on the right could be that which led to the Maze Garden. It is interesting, too, that an inner room is shown at the gallery's end, in the foreground. At the very least, this provides a sense of how Theobalds's 'cabinet' or 'Lodginge Roome' may have been arranged. Moreover, if the view is of Theobalds - or inspired by it - then the painting has significance as being the only fully illustrative interior depiction of the house known to exist.

In terms of its decoration, the Great Gallery featured a chimneypiece matching the others in the state apartment. Installed shortly before the queen's visit of 1591, it was of black and white marble, with eight columns and an overmantel bearing 'Divers carved and painted figures of horse and men'. ${ }^{181}$ Justus Zinzerling, a visitor of $c$. 1610, implies that it was inscribed in French with the history of 'Joannes de Sitschitz' and 'Guil. Fanacham', a moment of heraldic significance to the Cecil family. ${ }^{182}$ The gallery's walls were panelled, and above were paintings of various cities. These were complete by 1592, for in that year Rathgeb recorded seeing 'very artistic paintings and correct landscapes of all the most important and remarkable towns in Christendom'. ${ }^{183}$ In 1602, Frederic Gerschow added that these depicted 'the most splendid cities in the world and their garments and fashions'. ${ }^{184}$

Hung around the gallery's walls were, according to Baron Waldstein, portraits of 'the Roman Emperors from Julius Caesar to Domitian', as well as some of the knights-commanders of the Golden Fleece, the English kings Richard III, Henry IV, Edward IV, Henry V, VI and VII, and - on the opposite wall to the kings - portraits of six noblemen who were prominent on the Continent: Don Juan of Austria (154778); Alessandro Farnese (1545-92), Duke of Parma; Lamoral (1522-68), Count of Egmont; the Admiral of France (1519-72); Louis (1530-69), Prince de Condé; and the 


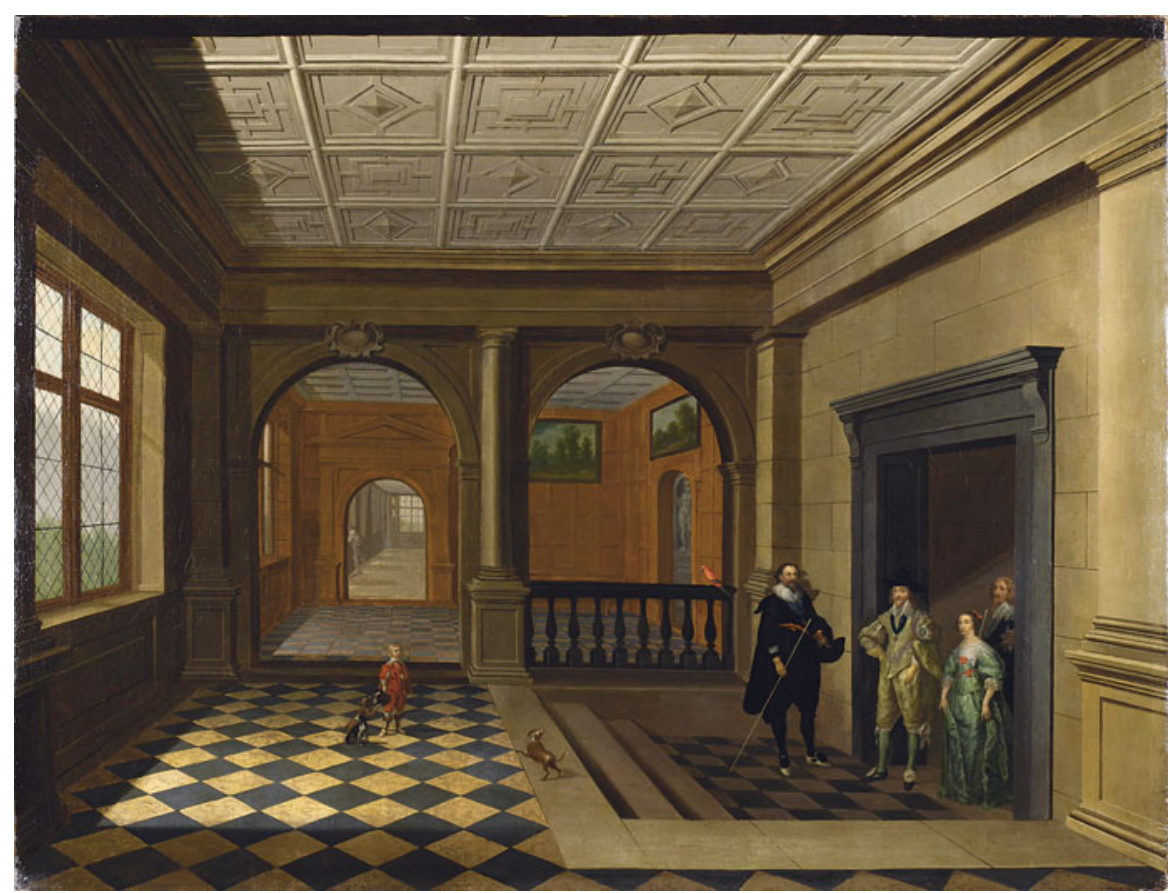

Fig. 18. Interior view of King Charles I and Queen Henrietta Maria with William Herbert, third Earl of Pembroke, and his brother Philip Herbert, later fourth Earl of Pembroke, successive Lord Chamberlains; on the left is the court dwarf Jeffrey Hudson (ㄷ Crown copyright: UK Government Art Collection). The painting has been ascribed to artists including Hendrick van Steenwyck and dates from c. 1630-35. The background is said by tradition to be Theobalds, and may relate to the Great Gallery

Duke of Saxony (probably John Frederick [1503-54], Elector of Saxony). ${ }^{185}$ As James Sutton has noted, there seems to have been an emphasis on the number twelve in this decorative scheme - six portraits of English kings, six of men prominent in continental Europe, twelve Roman emperors and perhaps twelve knights of the Golden Fleece. Sutton's suggestion that there may have been twelve city views in the friezes on each side of the room seems sensible. ${ }^{186}$ The gallery is known to have contained busts of the twelve Caesars and a 'terrestrial globe' which was twelve spans (9 ft/2.7 m) in circumference. ${ }^{187}$ It is no wonder that overseas visitors commented upon this decorative scheme, and it is likely that Lord Burghley intended the room to have this effect, encouraging pride among visitors from abroad, educating his countrymen about European affairs, and emphasising the breadth of his own knowledge and connections.

Like the Privy Gallery of the Middle Court, the Great Gallery at Theobalds imitated royal long galleries by being placed at the inner end of the state apartment and leading nowhere. It formed the culmination of the new suite, and was clearly a magnificent room, used as the setting for grand entertainments. ${ }^{188}$ Nevertheless, like its royal 
equivalents, it would have been intended as a semi-private space, reflecting its proximity to the state bedchamber and associated inner rooms. The irony is that, although Queen Elizabeth clearly made use of the state rooms in the Conduit Court, she preferred to remain in her older, more limited and secluded accommodation in the Middle Court. In terms of its full usage, the Conduit Court was to experience its glory at another, later period.

THEOBALDS UNDER SIR ROBERT CECIL, EARL OF SALISBURY (1598-1607), AND JAMES I AND CHARLES I (1607-49)

Few substantial changes appear to have been made to the plan of Theobalds between the completion of the Conduit Court and the death of Lord Burghley in 1598. However, alterations were certainly made by Sir Robert Cecil, and these seem to have been more extensive than has previously been recognised. Detailed records of the changes do not survive, though references to them provide useful evidence. Work was in train in the gardens and apparently on the house by $1602 .{ }^{189} \mathrm{~A}$ visitor of that year commented that of Theobalds's five courts, 'the last was not quite finished' ${ }^{190}$

Rebuilding was still under way, or was re-initiated, around March 1605. On 2 April that year, Humphrey Flynt, the keeper of Theobalds Park, wrote to Cecil that 'Your works appointed to be done about the house be in hand and there shall be as much speed made of them as possible'. ${ }^{191}$ On 22 May 1605, Sir Fulke Greville wrote to Cecil following a visit to Theobalds:

In your buildings I have some little quarrel to the windows of your new old gallery. I mean those next to the leaded terrace .... The alterations in your lodgings is passing good and will amend them both for sight and use exceedingly; yet if the old windows even in them had been carried up a little higher the commodity would thoroughly have recompensed for any little eyesore without, if any such must have grown by it, which I doubt of. ${ }^{192}$

Greville's reference to the 'new old gallery', which lay adjacent to a leaded walk, indicates one of two rooms: the great chamber or the Great Gallery of the Conduit Court (see Fig. 4). As to the lodgings, this reference must include the state apartment of the Conduit Court, and almost certainly that of the Middle Court also. Confirmation that changes were under way in these areas, and in other parts of the house, is given by bills for painters' work undertaken in 1605 and $1606 .{ }^{193}$

As has been recognised, ${ }^{194}$ Robert Cecil's programme of work included the interior of the west great chamber, which, in August 1602, Roger Houghton, Cecil's head of household at Theobalds, referred to as the 'great chamber gallery'. ${ }^{195}$ The extravagant decoration created by Lord Burghley was apparently still in place in 1600, when Baron Waldstein visited and described the room, although he made no mention of the mechanical ceiling. Two years later, in June 1602, the trees in the room's interior seem to have been in situ. ${ }^{196}$

However, it is notable that, on visiting Theobalds on 20 September 1602, the Duke of Stettin-Pomerania and his party were 'first led into a beautiful room panelled with chestnut wood, and in many places richly gilt. In the windows were placed the coats-of-arms of the principal potentates of the world. ${ }^{197}$ This probably describes either the north 
parlour or the great chamber and, if the latter, indicates that the room's interior was reworked in the summer of that year. Certainly, by May 1607 - when Theobalds became a royal palace - Lord Burghley's scheme had gone, there being no mention in the Royal Works accounts of its removal. In 1650, the interior of the great chamber was described as being

wainscotted round wth carved wainscott of good oake and varnished, and coullered of A liver couller, and richlie gilded with gold, with Antick pictures over ye same, selled with A plastered fret seelinge full of gilded pendance hanginge Downe, settinge forth the Roome with greate splendor. ${ }^{198}$

The black and white marble chimneypiece remained, but the room's grotto, mechanical ceiling and trees were all gone. Furthermore, the second (alabaster) chimneypiece referred to by Waldstein is not subsequently mentioned in accounts, and may have also been removed at this time. The restrained and elegant scheme described in the survey was already in place in 1610-11, when royal officers re-gilded and re-varnished the room's wainscot panels, which were sketched by John Smythson in 1618. ${ }^{199}$

A reworking of the great chamber's interior appears, therefore, to have been carried out either in summer 1602, with the knowledge and expectation that a new monarch would accede to the English throne, or around 1605, when royal favour of Theobalds had been made clear. As well as redecorating the great chamber, Robert Cecil seems to have heightened its windows, work implied by Greville's letter. Once the room's mechanical ceiling had been removed, there would have been extra space at the upper level. Cecil probably made use of this in reworking the interior, placing the new plaster ceiling at a greater height and carrying the windows up accordingly. Around the same time, Cecil may have made at least one other notable alteration to the state apartment, by curtailing the size of the privy chamber and bedchamber and creating a withdrawing chamber between them (see above). ${ }^{200}$

It has been generally assumed that Robert Cecil was reluctant to give up Theobalds, and that the 1607 act of exchange was testament to Cecil's loyalty and sense of devotion to his royal master. ${ }^{201}$ However, while Cecil was certainly devoted to James I, this assumption appears to be incorrect. During his lifetime, Lord Burghley had predicted that Theobalds 'would be too big for the small living he could leave his son'. ${ }^{202}$ A letter of June 1602 implies Robert was considering selling the house and estate, ${ }^{203}$ and in an undated letter to his friend Michael Hickes (pre-dating Hickes's knighthood in August 1604), Cecil wrote, 'I have nothing to say to Theobalds but yt I wish it less'. ${ }^{204}$ The arrival of James I and Queen Anne in England in 1603 and their evident admiration of Theobalds must, in this context, have been something of a godsend for Cecil, who may have been contemplating sale to the Crown even before that point.

Even better for Cecil, sale proved unnecessary. In summer 1606, transfer to the Crown began to be considered, and the following year Theobalds was formally exchanged for some prime royal property, including the estate at Hatfield which would henceforth become Sir Robert's principal home. ${ }^{205}$ Officially, Theobalds became one of the properties of Queen Anne - who gained formal possession of it on 22 May 1607 - since Hatfield had formed part of her jointure. 
Despite the transfer, however, the Cecil association with Theobalds continued. In July 1607, Sir Robert was given responsibility for supervising the royal works at the house, along with the Earls of Suffolk and Worcester. ${ }^{206}$ In May 1619, his son, William Cecil (1591-1668), second Earl of Salisbury, was made keeper of Theobalds, and was granted the house called The Laundry, on the north of the Middle Court. ${ }^{207}$ Charles I granted the keepership to the earl's son, Charles (1619-60), Lord Cranborne, in July 1628 , along with The Laundry. ${ }^{208}$

On acquiring Theobalds as a royal property, James I had the opportunity to adapt the planning of Lord Burghley's country house, but it is notable that so few alterations were made - either in 1607 or at any point thereafter. Repairs and restoration were obviously undertaken, and service buildings and porters' lodges were added. ${ }^{209}$ Rooms in the house were reworked and - in the case of the Green Gallery and long gallery over the hall - subdivided. ${ }^{210}$ Additionally, in 1607, the loggia on the ground floor of the projecting gallery range was enclosed to form a series of rooms. ${ }^{211}$ As regards the two state apartments, these were allocated to the queen (second floor of the Middle Court) and king (first floor of the Conduit Court), and royal terminology was adopted - for instance, the great chambers became known as presence chambers. However, the planning of both suites seems to have remained untouched. Instead, the Royal Works concentrated on the apartments' decoration, especially the addition of the royal arms, aiming to leave the house's new ownership in no doubt. ${ }^{212}$

On James I's death in 1625 - an event that occurred at Theobalds - Charles moved into the king's suite. There, in 1629-30, he made improvements, creating a timber staircase 'for his ma ${ }^{\text {tie }}$ to come downe out of his Bedchamber' into the gardens. ${ }^{213}$ Soon after this, in 1630-33, royal workmen carved and painted a large number of stags' heads and fixed them up in the Great Gallery, the panelling of which had been replaced in 1623-24. ${ }^{214}$ Queen Henrietta Maria moved into the queen's lodgings in the Middle Court and seems to have been given exclusive use of the chapel. ${ }^{215}$ Earlier, in July 1624, there had been plans for the building of a new chapel - presumably a Catholic one - along with a new bedchamber, other rooms and a tennis court. ${ }^{216}$ However, the improvements did not come to pass, and Theobalds retained its Elizabethan integrity until its demolition in 1650.

\section{CONCLUSION}

There can be no doubt that, had Theobalds survived, it would now be one of the most notable and admired sixteenth-century country houses in England, rated at least as highly as buildings such as Burghley House, Kirby Hall and Hardwick Hall (1591-97). As a former royal palace, it would also have a claim to be considered alongside Hampton Court. Reflecting the position, influence and architectural and artistic knowledge of Lord Burghley and the circle in which he lived, Theobalds was innovative in many ways. For instance, the Renaissance-style frontispiece (of 1568-69) of the hall range, with its loggia on the ground floor, must have been one of the first examples of such a feature in domestic architecture in England. Architectural components such as balconies, compass windows and magnificent long galleries also made early 
appearances in this country, while the house's great staircase - built originally in the late 1560 s and probably altered in $c .1582$ - was one of the earliest of its type in England. ${ }^{217}$

On account of Theobalds's early demolition, its identity as the source of inspiration for other buildings of its period and type is often overlooked. Nonetheless, there can be no question that it was influential, and widely so. For Summerson, Theobalds was, 'with the possible exception of Longleat and Wollaton, the most important architectural adventure of the whole of Elizabeth's reign' ${ }^{218}$ Its exterior design clearly served as a model for many of the great houses of the later 1500 and early 1600 . For instance, its arrangement of a great hall behind a loggia can be found at Knole, while at Burghley House (as rebuilt in 1573-88) and Hatfield House - both Cecil properties - the hall ranges are faced with a stone frontispiece with a loggia on the ground floor, as at Theobalds. Later examples of this arrangement include Bramshill (the frontispiece being an addition of c. 1619), as rebuilt by Edward, Lord Zouche, who had been a ward of Lord Burghley and knew Theobalds well. This element of Theobalds also found its way overseas: Patrick Kragelund has argued that the stone frontispiece or 'Marble Gallery' in the inner courtyard of Frederiksborg Palace in Denmark (an addition of 1619-21) was almost certainly inspired by that at Theobalds, witnessed first-hand by the builder of Frederiksborg, King Christian IV, on his visit to England in 1606. ${ }^{219}$

As regards other distinctive elements of Theobalds's exterior design, the single-storey block on the north side of the Conduit Court can be seen to have inspired the singlestorey block (containing the great hall) on the west side of the inner courtyard at Audley End. In both cases, the ranges were the only single-storey blocks in the courtyard, the others rising through two or more levels. Audley End also had prominent corner towers, which are likely to have been based on those at Theobalds - an especially appropriate precedent, as Audley End was similarly built by a Lord Treasurer keen to impress, entice and accommodate the monarch and the royal court.

The plan of Theobalds was clearly also used as a model by many high-status country house builders. For example, Holdenby - known to have been based specifically on Theobalds - had its state rooms at second-floor level, as in the Middle Court of Lord Burghley's house. ${ }^{220}$ This was, by the 1570s, an uncommon arrangement in a house of Holdenby's size, but its builder, Sir Christopher Hatton, clearly thought it was one worthy of imitation. Hatton's principal great chamber was in an identical position that is, on the south side of the double-height great hall - though the inner state rooms and long gallery were arranged double-pile, Holdenby not including the projecting gallery range of Theobalds. At Holdenby, as at Theobalds, Hatton also placed a long gallery above the double-height great hall. Later, this arrangement was created at Knole, where the attic room above the great hall survives as the Retainers' Gallery.

The stacking of loggia, long gallery and roof-top walk, as in the east (entrance) range of Theobalds, was another element of the plan imitated - in an identical position - at Holdenby, in the gatehouse block on the east side of the first main courtyard. Such an arrangement can also be found (with the addition of an attic gallery) in the east range of Apethorpe Hall - as rebuilt in 1622-24 at the command of King James - and in the south (entrance) range of Castle Ashby, as rebuilt in the 1620 s or 1630s. Even the more unsuccessful elements of Theobalds's plan had an impact: the projecting gallery range, added as an afterthought by Lord Burghley in the early 1570s, seems to have 
served as the inspiration for a similar three-storey projecting range (begun c. 1612) at Christian IV's Frederiksborg Palace. ${ }^{221}$ This contained the Privy Gallery on its upper floor and culminated, as at Theobalds, in a tower.

In its interior decoration, Theobalds was also a source of influence and inspiration. The use of trees in a decorative scheme - a dominant feature of Theobalds's Green Gallery and principal (west) great chamber - was imitated in the great chambers of Gilling Castle (c. 1585) and Hardwick Hall. The provision of a 'wainscott case' or window overlooking the great hall from the state rooms was copied at Hatfield House, where the feature opens off the extension of the first-floor long gallery, at the low end of the hall. The great staircase at Hatfield is also believed to have been modelled on the one at Theobalds, while Hatfield included a double-height chapel with painted windows, as at Sir Robert Cecil's childhood home. ${ }^{222}$

Following the reconstruction of the plan and interiors of Theobalds set out in this article, it is possible to be much more confident in identifying Lord Burghley's house as a model or source of inspiration. This article argues for a greater recognition of the significance of Theobalds, both in Britain and at an international level, and of its builder, the great Lord Burghley. There can be no doubt that it found its way into country house architecture for generations. Theobalds need not be an enigma. As this article has shown, the evidence we have is detailed and comparatively substantial, and there is almost certainly a great deal more evidence out there, awaiting future discovery.

\section{ACKNOWLEDGEMENTS}

This article has been written over a period of years, and emerged from my DPhil studies. I am very grateful to my supervisor, Professor Maurice Howard, for all his encouragement and advice, and for reading the text. I am also grateful to Kathryn Morrison for reading the draft text and for providing comments, and to John Cattell and Pete Herring at Historic England (formerly English Heritage), who allowed me to take time out of work to undertake further research. I owe a particular debt to Robin Harcourt Williams and Vicki Perry, Archivists at Hatfield House, to my colleagues Allan Adams and Phil Sinton at Historic England, who prepared drawings for me, and to my father B.J. Cole, for nurturing and sharing my enthusiasm about the history of Theobalds and Enfield more generally. Others to whom I would like to express my gratitude are: Paul Backhouse (Historic England), Martin Dearne (Enfield Archaeological Society), Mike Dewbrey (Enfield Archaeological Society), Claire Gapper, Esther Godfrey (Historic England), Stewart Hoad (MOLA), Patrick Kragelund, Richard Lea (formerly of English Heritage), Patrizia Pierazzo (formerly of MOLA), Edward Town, the Archivist at Chatsworth House, the editorial team of Architectural History, and all those who have kindly granted me permission to reproduce images and who have discussed Theobalds with me over the years.

\section{BIOGRAPHY}

Emily Cole is Senior Investigator in the Research Group of Historic England, based in Cambridge, and was formerly Head of the Blue Plaques Team at English Heritage. She holds an MA from the Courtauld Institute of Art: her thesis focused on the impact of royal progresses on Elizabethan country houses. In 2011, Emily completed a doctorate at Sussex University on state apartments in Jacobean country houses. She has edited and contributed to various books, including 
Apethorpe: The Story of an English Country House (2016), and is author of Historic England reports including The Urban and Suburban Public House in Inter-War England (2015).

\section{ABSTRACT}

This article aims to reconstruct the plan of Theobalds, Hertfordshire, built between 1564 and 1585 by Sir William Cecil, Lord Burghley. Theobalds was perhaps the most significant English country house of the Elizabethan period and in 1607 was taken on as a royal palace. It was visited by all the major court and political figures of the age, while its fame also extended overseas. Theobalds was innovative in various respects, as the article makes clear, and it had a profound impact on the architecture of its generation. Its importance is all the more extraordinary given that Theobalds was so short-lived: the house was taken down shortly after 1650 and few traces of it survive today. The assumption has been that, because the house was demolished so long ago, it could not be well understood. This article contradicts that view by reconstructing in detail the plan of Theobalds, using evidence provided by primary documents.

\section{NOTES}

1 The site of the house now forms part of Cedars Park, Cheshunt, which includes remains such as brick walls with stone dressings. The site has never been fully excavated.

2 One sketch appears in a coloured map of 1611 by the surveyor John Thorpe: London, British Library [hereafter 'BL'], Cotton MS Augustus I i 75. Another was published by the printseller Peter Stent in 1653; see E.J. Priestley, 'Pictured Palaces', Country Life, 182, 24 (16 June 1988), pp. 178-80.

3 John Summerson, 'The Building of Theobalds, 1564-1585', Archaeologia, 97 (1959), pp. 107-26.

4 The History of the King's Works, Volume IV: 1485-1660 (Part II), ed. Howard Colvin (London, 1982), pp. 273-78.

5 Malcolm Airs, 'Pomp or Glory: The Influence of Theobalds', in Patronage, Culture and Power: The Early Cecils 1558-1612, ed. Pauline Croft (New Haven and London, 2002), pp. 3-20.

6 Martin Andrews, 'Theobalds Palace: The Gardens and the Park', Journal of Garden History, 14 (1994), pp. $129-49$.

7 James M. Sutton, 'The Decorative Program at Elizabethan Theobalds: Educating an Heir and Promoting a Dynasty', Studies in the Decorative Arts, Design and Culture, 7, I (1999-2000), pp. 33-64; James M. Sutton, Materializing Space at an Early Modern Prodigy House: The Cecils at Theobalds, 1564-1607 (Aldershot, 2004).

8 Ian Dunlop, Palaces and Progresses of Elizabeth I (London, 1962), pp. 167-76.

9 The schedules form part of the Cecil Papers at Hatfield House Archives: Hatfield House Archives [hereafter ' $\mathrm{HHA}^{\prime}$ ], Cecil Papers [hereafter ' $\mathrm{CP}^{\prime}$ ] 140/18 (draft) and CP 140/19 (final) (22 July 1572), CP 140/22-23 (draft) and CP 140/24 (final) (14 May 1577), CP 143/63-64 (draft), and CP 140/28-29 and CP 140/26 (final) (27 May 1583), CP 140/35 (draft) and CP 140/33-34 (final) (10 May 1591); other copies are CP 143/66-68. CP $143 / 69$ is an undated schedule, which can be confidently ascribed to 1591 . CP $143 / 66$ also relates to the royal visit of 1591 .

10 Summerson, 'Building of Theobalds', pp. 121-25, though pp. 117-18 also include relevant information.

11 Ibid., p. 125.

12 Summerson does not appear to have been aware of a letter by Charles Cavendish, for instance, cited later in this article in relation to the Conduit Court. Nor, apparently, was he aware of various references relating to building work at Theobalds undertaken during the time of Sir Robert Cecil (also mentioned below).

13 HHA, CP 143/31-32 is a design for the first floor of the Conduit Court, but is not closely related to the courtyard as built. Also possibly showing the upper floor is a plan of the gatehouse range; see Summerson, 'Building of Theobalds', pls XXVa and XXVIc.

14 London, Sir John Soane's Museum [hereafter 'SM'], T245-6 (ground floor) and T243 (basement). See John Summerson, 'The Book of Architecture of John Thorpe in Sir John Soane's Museum', Walpole Society, 40 (1966), pp. 8 and 105. The plans were almost certainly produced at the time when royal ownership of Theobalds began to be mooted, and probably include changes made to the house by Robert Cecil. Records show that Thorpe was paid in June 1606 to undertake a survey of Theobalds, and the resulting survey was specifically mentioned in February 1607: Summerson, 'Book of Architecture', p. 8. The plans he produced appear highly accurate, and 
tally with the evidence of other primary documents, including the parliamentary survey. This level of accuracy reflects the nature of the plans as new surveys. As a surveyor, Thorpe was very highly regarded, though as a copyist he may have been prone to error. Summerson wrote, 'Old plans would be readily available to him [Thorpe] to copy and it may be that sometimes his copies were rather free': Summerson, 'Building of Theobalds', p. 109. It should be noted that Thorpe's plans of Theobalds seem to have been trimmed, since they include only a small portion of the projecting gallery range, and in the ground-floor plan only the inner half of the east (gatehouse) range is shown.

15 The general layout of Theobalds as shown in Thorpe's basement and ground-floor plans has been used as the basis for the reconstructed plans in this article, providing the overall template for the house and its major room divisions, along with architectural features such as staircases. The more detailed arrangements shown above ground level are conjectural, though based on primary evidence. This is also the case for the outline plan of the projecting gallery range, not included on Thorpe's surveys.

16 The exterior reconstruction is indebted to a similar drawing published as the frontispiece of Dunlop's Palaces and Progresses, although the reconstruction in this article corrects a number of errors made in Dunlop's illustration. A reconstruction of the house from a different viewpoint - the south-west - was included in Summerson, 'Building of Theobalds' (p. 119).

17 Lord Burghley noted that it was the reception of the queen and her train that 'enforced' him to enlarge Theobalds: The Anonymous Life of William Cecil, Lord Burghley, ed. Alan G.R. Smith (Lewinson, Queenston and Lampeter, 1990), pp. 93-94.

18 For the queen's visits to Theobalds, see Mary Hill Cole, The Portable Queen: Elizabeth I and the Politics of Ceremony (Amherst, 1999), pp. 180-201.

19 Emily V. Cole, 'The State Apartment in the Jacobean Country House, 1603-1625' (doctoral thesis, University of Sussex, 2011), Appendix 2 (itinerary of James I).

20 London, National Archives [hereafter 'NA'], E317/Herts/26, p. 50.

21 Summerson, 'Building of Theobalds', p. 107. Summerson's article forms the basis for the following summary of the house's development.

22 Simon Bradley and Nikolaus Pevsner, The Buildings of England, London 1: The City of London (London, 1997; reprinted 1999), p. 328.

23 Summerson, 'Book of Architecture', p. 102: SM, T221-2. The design is not as executed: for instance, at that point in the process, it was intended that the great chamber be situated above the great hall.

24 HHA, CP Box G/16, ff. 16-17, CP 140/22-23, CP 140/24.

25 HHA, CP 143/31-32, Summerson, 'Building of Theobalds', pl. XXVa and p. 114. Hawthorne's plan seems to show twin state apartments on the first floor, joined by a long gallery. Mark Girouard sees this as evidence that Burghley was anticipating a royal marriage: Girouard, Elizabethan Architecture (New Haven and London, 2009), p. 113.

26 HHA, CP Box G/16, ff. 43v-44.

27 HHA, CP 143/56.

28 Summerson, 'Building of Theobalds', p. 114; HHA, CP 143/58, CP 143/57, CP 143/59.

29 Historical Manuscripts Commission [hereafter 'HMC'], The Manuscripts of His Grace, the Duke of Rutland Preserved at Belvoir Castle, Volume 1 (London, 1888), p. 150.

30 NA, E317/Herts/26, pp. 20 and 22.

31 Ibid., p. 9.

32 Ibid., p. 24. Summerson erroneously shows the hall roof as pitched in a reconstruction drawing: 'Building of Theobalds', pl. XXXIIb.

33 NA, E317/Herts/26, p. 10.

34 HHA, CP 140/22-23. It was probably in this area - 'Inside the gate house' - that Baron Waldstein found the container 'elaborately constructed to look like a bunch of grapes' which, during the queen's visits, was fed with 'white wine from one part of it and red wine from another': The Diary of Baron Waldstein: A Traveller in Elizabethan England, ed. G.W. Groos (London, 1981), p. 83.

35 Summerson, 'Building of Theobalds', p. 109; 'Book of Architecture', p. 77. Summerson suggested that another Thorpe elevation (SM, T108) is also related to Theobalds. However, I do not believe this is the case. The drawing is inscribed 'The garden syde lodgings below \& gallery above' and shows a range of two main storeys with an attic. If it relates to Theobalds, it can only show the west side of the projecting range or the west side of the Conduit Court, both of which contained long galleries. Both ranges, however, are known to have included towers, and these are not depicted. A (more likely) alternative suggested by Summerson is that the drawing relates to Apethorpe Hall in Northamptonshire. 
36 The Journal of Sir Roger Wilbraham, ed. H.S. Scott (London, 1902), p. 23.

37 Girouard, Elizabethan Architecture, p. 267 and fig. 319.

38 NA, E317/Herts/26, p. 20.

39 Ibid., p. 3.

40 Ibid., p. 13.

41 HHA, CP 143/59.

42 NA, E317/Herts/26, p. 3.

43 Longleat may well have been the inspiration for this aspect of Theobalds, since the plans for this phase of Longleat's rebuilding are thought to have been drawn up in 1567 (a model of the new design was produced in that year, following a fire in April): Mark Girouard, Robert Smythson and the Elizabethan Country House (New Haven and London, 1983), p. 46.

44 NA, E317/Herts/26, p. 5 .

45 HHA, CP 140/18-19.

46 NA, E317/Herts/26, p. 3.

47 For example: HHA, CP 140/18-19, CP 140/22-23.

48 This cellar, shown on Thorpe's basement plan of Theobalds (SM, T243), was given over to the queen during her visits; see, for instance, HHA, CP 140/22-23. It was probably this cellar that the survey described as being 'archt over with curious workemanshipp': NA, E317/Herts/26, p. 2.

49 NA, E317/Herts/26, p. 12.

50 Ibid.

51 HHA, CP 140/33-34.

52 HHA, CP 140/22-23, CP 140/28-29, CP 140/33-34, CP 143/69, CP 140/18-19. By 1650, the 'Queenes roabes roome' was based in the former chaplain's chamber: NA, E317/Herts/26, p. 12.

53 HHA, CP 140/22-23.

54 Ibid. and HHA, CP 140/28-29, CP 143/69.

55 NA, E317/Herts/26, pp. 18-19. The Royal Works accounts refer to the 'prince's gallery'; see, for instance, NA, E351/3256, f. 11.

56 HHA, CP 140/22-24.

57 HHA, CP 140/18-19, CP 140/24.

58 HHA, CP 140/22-23.

59 HHA, CP 140/18-19, CP 140/33-35. The lodging had also been allocated to Raleigh, with others including Fulke Greville, in 1577 and 1583: HHA, CP 140/22-23, CP 140/28-29.

6o HHA, CP 140/22-23.

61 NA, E317/Herts/26, p. 12.

62 HHA, CP 140/22-23, CP 140/28-29.

63 HHA, CP $140 / 28-29$.

64 HHA, CP 140/22-24, CP 140/28-29, CP 140/33-34, CP 143/69.

65 HHA, CP 140/22-23; NA E351/3243, f. 42.

66 NA, E317/Herts/26, p. 15.

67 W.B. Rye, England as seen by Foreigners in the Days of Elizabeth and James the First (London, 1865), p. 45.

68 Diary of Baron Waldstein, p. 87.

69 'Diary of the Journey of Philip Julius, Duke of Stettin-Pomerania, Through England in the Year 1602', ed. G. Von Bulow, Transactions of the Royal Historical Society, 6 (1892), p. 31.

70 NA, E317/Herts/26, p. 15; Jean-Albert de Mandelslo, Voyages Celebres $\mathcal{E}$ remarquables, faits de Perse aux Indes Orientales, trans. A. de Wicquefort (Amsterdam, 1727), p. 737. Mandelslo's description of the house is given in French, but has been translated by me for quotation in this article.

71 See introduction by William Ravenhill in Christopher Saxton's $16^{\text {th }}$ Century Maps: The Counties of England and Wales (Shrewsbury, 1992), p. 13.

72 HHA, CP 140/33-34.

73 See, for instance, HHA, CP 140/18-19.

74 NA, E317/Herts/26, p. 13.

75 Ibid.

76 HHA, CP 140/22-23, CP 140/28-29; NA, E317/Herts/26, p. 14.

77 See, for instance, HHA, CP 140/22-23.

78 NA, E317/Herts/26, p. 14.

79 Journal of Sir Roger Wilbraham, p. 23. 
80 HHA, CP 140/18-19.

81 The state apartment at Holdenby, a house known to have been modelled on Theobalds, included a gallery in the same general position. See Cole, 'State Apartment', pp. 190-91, fig. 60.

82 HHA, CP 140/22-23, CP 143/63-64, CP 140/28-29, CP 140/33-34.

83 NA, E317/Herts/26, pp. 14-15, 25.

84 Ibid., p. 15 .

85 Ibid., p. 14 .

86 The schedules of accommodation show that all the chambers in this area of the house were in use by the queen and her attendants during royal visits, and it is difficult to suggest reasons why such a large room would not have been similarly allocated. It is highly unlikely to have been one of the two inner rooms used by the queen's 'chamberers', as one of these was certainly small and unheated and, on the reconstructed plan (see Fig. 4), both fit neatly into the space to the immediate east of the back staircase. In general, rooms at Theobalds seem only to have been unallocated during royal visits when they had an existing or private use by members of the Cecil family or household, and this cannot have been the case with the Coffer Chamber. Had it existed as a separate chamber in the Elizabethan period, it would have been a key component of the queen's state apartment, between her inner state rooms and her long gallery.

87 NA, E317/Herts/26, pp. 25 and 15.

88 Given its location, and the need for privacy and security when the queen was at Theobalds, it is no surprise to find that this tower chamber was unallocated during the royal visits of 1577 and 1583 and is not mentioned in schedules of 1591. The schedule of 1572 groups the two tower lodgings together, allocating them to 'my Lord Carewe \& the La and gentlewomen of the bedchamber': HHA, CP 140/18-19. This seems to be a reference to Sir Peter Carew (?1514-75), then serving as Constable of the Tower of London.

89 Cole, 'State Apartment', pp. 187-89.

90 HHA, CP 143/63-64; NA, E317/Herts/26, p. 17.

91 HHA, CP 143/69; NA, E351/3242, f. 19v.

92 NA, E317/Herts/26, p. 17. If, as suggested, the Queen's Coffer Chamber formed part of the Privy Gallery until c. 1605 , its original length would have been greater.

93 Also of note is the barrel-vaulted long gallery at Gorhambury, Hertfordshire, on the first floor of a projecting range constructed for a visit of Elizabeth I. This was built by Burghley's brother-in-law, Sir Nicholas Bacon, sometime between 1572 and 1577. It was therefore contemporary with Theobalds's Privy Gallery and was probably influenced by it, though it is also possible that the gallery at Gorhambury provided Burghley with his inspiration.

94 NA, E317/Herts/26, p. 17.

95 'Diary of Philip Julius, Duke of Stettin-Pomerania', p. 31. According to Roger Wilbraham, Theobalds included ' 3 galleries painted with the trees of ech shire': Journal of Sir Roger Wilbraham, p. 23. The Green Gallery and the Privy Gallery seem to have been two of these. Possibly, the gallery over the great hall was the third, or the great chamber in the Conduit Court, frequently referred to as a 'gallery' around that time.

96 Mandelslo, Voyages Celebres, p. 737.

97 For evidence of this tower, see HHA, CP 140/28-29. No tower is shown in the surviving drawing of the range's west elevation (see Fig. 10). Presumably, it was altered in execution, though no obvious tower is shown in Thorpe's 1611 map either (BL, Cotton MS Augustus I i 75). For the reconstruction drawings in this article, it has been assumed that a tower did exist, not least because it allowed space for the rooms known to have been located at this end of the gallery.

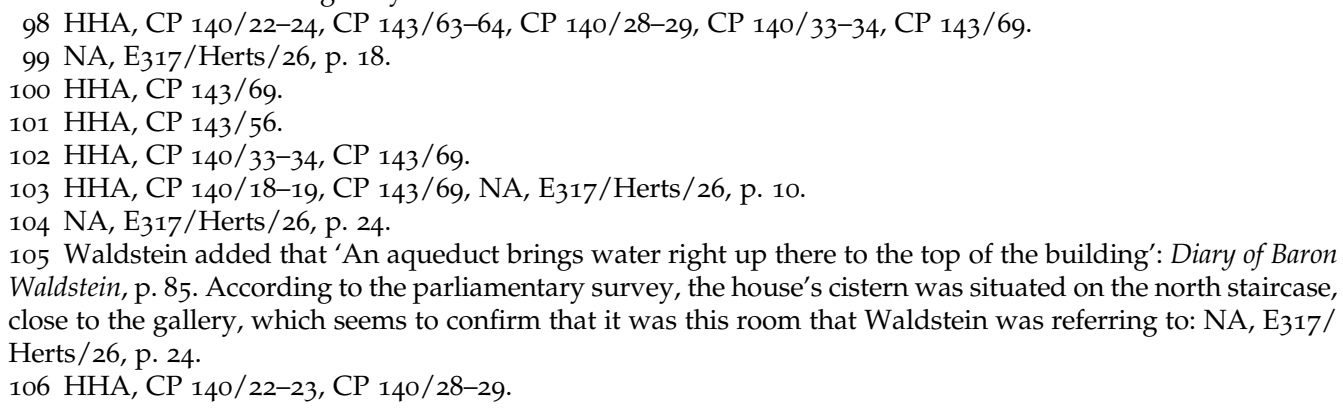


107 NA, E317/Herts/26, p. 10. Probably, the gallery extended through the length and width of the central part of the hall block, which measured $86 \mathrm{ft}(26.2 \mathrm{~m})$ by around $25 \mathrm{ft}(7.6 \mathrm{~m})$.

108 Ibid., pp. 8-9.

$109 \mathrm{HHA}, \mathrm{CP}$ 140/22-23, CP 140/28-29.

110 HHA, CP 140/22-23.

111 In his will, Lord Burghley referred to 'my bedchambers pallette chambers or chambers used for suiters to resorte unto me': NA, PROB $11 / 92 / 316$, p. 6.

112 HHA, CP 140/22-23, CP 140/28-29.

113 HHA, CP 140/33-34. During this visit, Burghley's lodging was allocated to the Lord Chancellor, the then very unwell Sir Christopher Hatton.

114 HHA, CP 140/33-34.

115 HHA, CP 140/28-29.

116 HHA, CP 140/18-19.

117 NA, E317/Herts/26, pp. 10-11, 24.

118 Ibid., pp. 24, 10.

119 Diary of Baron Waldstein, p. 85.

120 Evidence of the use of the roof walks is provided by Sir John Finet, Master of Ceremonies to James I. Writing of the king's audience of an ambassador at Theobalds in c. 1619, he stated that 'he was introduced to his Audience by a private way over the Leads into the Prevy Gallery' [i.e. Great Gallery]: Sir John Finet, Finetti Philoxenis (London, 1656), p. 62, also p. 138.

121 NA, E317/Herts/26, p. 11.

122 Ibid., p. 5 .

123 Ibid.

124 Ibid.

125 For the royal visit of 1591, this 'longe dyninge place' was used 'for the Lord Treasurer's table': HHA, CP $143 / 69$.

126 J.G.N. [John Gough Nichols], 'Theobalds Palace', Gentleman's Magazine (September, 1836), pp. 262-63. See also NA, PROB 11/92/316, p. 6. The former source gives the year as 1577, but the twenty-ninth year of Queen Elizabeth's reign, as mentioned in Burghley's will, equates to 1587.

127 NA, E351/3243, f. 42V, NA, E317/Herts/26, p. 43. Documents from the Elizabethan period do not name these rooms, and they were not allocated to guests for royal visits. This underlines the probability that they were used by a member of the Cecil family.

128 Ibid., pp. 4-5.

129 HHA, CP 143/69, CP 140/33-34.

130 HHA, CP 140/33-34.

131 Ibid.

132 NA, E317/Herts/26, p. 4. The bedchamber in this lodging was almost certainly the 'tarras chamber' of earlier years; see HHA, CP $143 / 69$.

133 NA, E317/Herts/26, p. 3.

134 Ibid., p. 23.

135 J.G.N., 'Theobalds Palace', Gentleman's Magazine (February 1836), p. 150; Diary of Baron Waldstein, p. 85.

136 Mandelslo, Voyages Celebres, p. 737.

$137 \mathrm{HHA}, \mathrm{CP} 143 / 58$.

138 In a letter of 1579 written from Holdenby to his absent host, Sir Christopher Hatton, Burghley stated, 'I found no one thing of greater grace than your stately ascent from your hall to your great chamber'; quoted in Emily Sophia Hartshorne, Memorials of Holdenby (London, 1868), p. 15.

139 NA, E317/Herts/26, p. 6.

140 Ibid., p. 24. The 'head of the greate staires' was adjacent to the second-floor great chamber of the Middle Court: ibid., p. 13 .

141 Ibid., p. 6.

142 Summerson, 'Building of Theobalds', p. 122.

143 NA, E317/Herts/26, p. 6.

144 Rye, England as seen by Foreigners, p. 44.

145 John Strype, Annals of the Reformation and Establishment of Religion, new edition (Oxford, 1824), p. 381.

146 Chatsworth, Devonshire MSS [hereafter CD], Hardwick drawers, H/143/16. It is notable that Cavendish's letter makes reference to the 'ould trees' being 'thir still'. It would seem that the trees constituted an early stage 
in the room's decoration: perhaps they were added in c. 1582 as the first component in a larger scheme, or perhaps the room's interior was made more extravagant following criticism made by the queen.

147 Rye, England as seen by Foreigners, p. 44.

148 Diary of Baron Waldstein, p. 83.

149 HHA, CP 143/59, CP 143/69, CP 140/33-34.

150 BL, Lansdowne MS 43/14 (letter from Sir John Yonge to Lord Burghley, 24 August 1584).

151 Rye, England as seen by Foreigners, p. 44.

152 Diary of Baron Waldstein, p. 83.

153 Rye, England as seen by Foreigners, p. 44.

154 CD, Hardwick drawers H/143/16; HHA, CP 143/59; Diary of Baron Waldstein, p. 83.

155 NA, E317/Herts/26, p. 6.

156 Models of the terms for the chimneypiece were made by the carvers John Degrave and 'Jaques' in 1581 , altered by the carver Arnold Rivers, and in the following year cast in metal by the gunfounder Henry Pitt: HHA, CP 143/57. Among the Cecil Papers is an 'estimate' of the chimneypiece and a drawing of the marble required for its construction: HHA, CP 143/36, CP 143/34.

157 NA, E317/Herts/26, p. 6; 'Diary Philip Julius, Duke of Stettin-Pomerania', p. 31. For Henry Hawthorne's design for one of these windows, see CP 143/33; and Summerson, 'Building of Theobalds', pl. XXVIIb.

158 HHA, CP 140/33-34; NA, E317/Herts/26, p. 6.

159 NA, E317/Herts/26, p. 6.

160 Ibid., p. 7; and, for example, NA, E351/3242, f. $19 \mathrm{v}$.

161 NA, E317/Herts/26, p. 7 .

162 Ibid.

163 Ibid.

164 NA, E351/3247, f. 12.

165 NA, E317/Herts/26, p. 7; NA, E351/3249, f. 13v.

166 HHA, CP 140/33-34.

167 NA, E317/Herts/26, p. 7 .

168 Ibid., p. 24.

169 NA, E351/542, f. 91; HHA, CP 140/33-34.

170 NA, E317/Herts/26, p. 7 .

171 Ibid.

172 Rathgeb stated that the room shown in his sketch had a ground 'prettily ornamented with blue colours, but the roses and other ornaments are gilded': Rye, England as seen by Foreigners, p. 45. The mention of roses and gilding suggests it was the ceiling of the Great Gallery, as later described in the parliamentary survey. I am grateful to Claire Gapper for her advice on this ceiling.

173 NA, E317/Herts/26, p. 8.

174 Ibid., p. 24.

175 Ibid., p. 7 .

176 Mandelslo, Voyages Celebres, p. 737 .

177 NA, E351/3254, f. 10v.

178 Margaret R. Toynbee, 'A Charles I Conversation Piece', The Burlington Magazine for Connoisseurs, 89, 534 (September, 1947), pp. 244-47. Others believe that the backdrop of the painting is completely imaginary. Simon Thurley, for instance, takes this view: personal communication, 28 August 2007.

179 Toynbee, 'Charles I Conversation Piece', p. 246.

180 The Royal Works accounts of 1626-27 mention 'the lower passage where his Maty cometh downe the greate staires from his gallerie': NA, E351/3260, f. 7. This must refer to the area at the foot of the stone staircase at the north-west end of the Great Gallery.

181 HHA, CP 143/65; NA, E317/Herts/26, p. 8.

182 Rye, England as seen by Foreigners, p. 135; G. Ravenscroft Dennis, The House of Cecil (London, 1914), pp. 2-3.

183 Rye, England as seen by Foreigners, pp. 44-45.

184 'Diary of Philip Julius, Duke of Stettin-Pomerania', p. 31.

185 Diary of Baron Waldstein, p. 85.

186 Sutton, 'Decorative Program at Elizabethan Theobalds', p. 44. It should be noted that there were six trees on each side of the Conduit Court's great chamber, so the theme may have extended beyond the gallery.

187 Diary of Baron Waldstein, p. 85. 
188 The masque staged by Robert Cecil for King James and Queen Anne in May 1607 is known to have been held in the Great Gallery: John Nichols, The Progresses, Processions, E Magnificent Festivities of King James the First, 4 vols (London, 1828), 2, p. 128; NA, E351/543, f. 174.

189 HMC, Calendar of the Manuscripts of the Marquis of Salisbury, 12 (Hereford, 1910), pp. 206, 242, 292, 316 and 380 .

190 'Diary of Philip Julius, Duke of Stettin-Pomerania', p. 31. This is probably a reference to a service court. $191 \mathrm{HMC}$, Salisbury, 17 (London, 1938), p. 127. I believe that this reference has not been cited before in relation to the architectural history of Theobalds.

192 Ibid., p. 215.

193 Edward Town has shown that Paul Isaacson carried out an 'extensive campaign' of painting at Theobalds between May and November 1605, and that the painter Rowland Buckett - later active at Hatfield House - was working at Theobalds in c. 1606-7: Edward Town, 'A Biographical Dictionary of London Painters, 1547-1625', Walpole Society, 76 (2014), pp. 1-235 (pp. 44-45, 114). Buckett carried out work in rooms including 'the Queenes w [th] drawinge Chamber', 'the Queenes Bedd Chamber', and the 'new painted Gallery', possibly a reference to the great chamber of the Conduit Court: HHA, Bills 12. Isaacson's programme of work included painting 'uppon the great stares': HHA, Bills 9.

194 Airs, 'Pomp or Glory', p. 15

195 HMC, Salisbury, 12, p. 319.

196 In that month, Sir John Harington visited Theobalds and saw the 'summer room' - almost certainly the great chamber (Arbour) - which prompted him to recall a verse in Ariosto's Enchantments, 'But which was strange, where erst I left a wood/ A wondrous stately palace now there stood': ibid., p. 18 .

197 'Diary of Philip Julius, Duke of Stettin-Pomerania', p. 31.

198 NA, E317/Herts/26, p. 6.

199 London, Royal Institute of British Architects, SC237/III/13; see Airs, 'Pomp or Glory', p. 14. The design of this panelling at Theobalds was used as the basis for that in the king's great chamber at Bramshill (1605-c. 1617), the long gallery at Hatfield House (1607-12), and the Pillar Parlour at Bolsover's Little Castle (begun 1612).

200 In 1606, Rowland Buckett submitted a bill for work including painting the chimneypiece and frieze of the 'Queenes w[th] drawinge Chamber': HHA, Bills 12. However, this is likely to refer to the withdrawing chamber in the Middle Court. By this point, the state apartment in the Conduit Court was probably allocated to the king rather than the queen.

201 For instance, James Sutton has written that Cecil was 'forced to give it [Theobalds] to King James': Sutton, 'Decorative Program at Elizabethan Theobalds', p. 34. Even John Summerson wrote of how James I 'persuaded' Cecil to exchange Theobalds for Hatfield: Summerson, 'Building of Theobalds', p. 125.

202 Anonymous Life of William Cecil, p. 94.

203 On 7 June 1602, Sir John Harington wrote to Robert Cecil, 'not far beyond Theballs I met with an old Norfolk gentleman, who told me he heard you would sell Theballs': HMC, Salisbury, 12, p. 188.

204 BL, Lansdowne vol. 107, f. 86 (no. 51).

205 John Thorpe was paid in June 1606 for surveys of Holdenby, Ampthill and Theobalds, all of which were to be taken on by the Crown: Summerson, 'Book of Architecture', p. 8. The transfer document described Theobalds as 'a place so convenient for his Mats princelie sportes and recreacon, and so comodious for the residence of his highnes Court, \& entertainement of forraine princes, or there Ambassadors upon all occasions, as his Matie hath taken great liking thereunto': NA, C89/10/55.

206 HMC, Salisbury, 19 (London, 1965), p. 253.

207 NA, E317/Herts/26, p. 51.

208 Ibid., p. 52.

209 History of the King's Works, Volume IV, p. 274.

210 NA, E317/Herts/26, pp. 15 and 10.

211 NA, E351/3242, f. 18; NA, E317/Herts/26, p. 16.

212 For instance, in c. 1607, the king's and queen's arms were painted on the wall in the Privy Gallery: NA,

E317/Herts/26, p. 17 .

213 NA, E351/3263, f. 12V.

214 NA, E351/3257, f. 16, E351/3264, f. 9, E351/3266, f. 12V.

215 This was known as the 'Queenes Chapple' by 1650: NA, E317/Herts/26, p. 12.

216 Calendar of State Papers, Domestic series, James I, 1623-25 (London, 1859), p. 307.

217 Summerson, 'Building of Theobalds', p. 122.

218 Ibid., p. 125. 
219 Patrick Kragelund, 'Christian IV's visit to Theobalds and the building of Frederiksborg Palace' (paper at $7^{\text {th }}$ New Insights into $16^{\text {th }}$ - and $17^{\text {th }}$-century British Architecture conference, Society of Antiquaries, London, 21 January 2017); Patrick Kragelund, A Stage for Denmark's Monarch: The Travels of Christian IV and the Building of Frederiksborg (Copenhagen, 2017). I am very grateful to Patrick for sharing with me a typescript copy of his forthcoming book and for discussing with me the various similarities between Theobalds and Frederiksborg. 220 In a modestly worded letter of 10 August 1579, written from Holdenby to his absent host Sir Christopher Hatton, Lord Burghley stated, 'where you were wont to say it [Holdenby] was a young Theobalds, truly Theobalds I like as my own; but I confess it is not so good as a model to a work, less than a pattern, and no otherwise worthy in any comparison than a foil': Hartshorne, Memorials of Holdenby, p. 15. For a reconstructed plan of the second (state) floor of Holdenby, based on the plan of John Thorpe, see Cole, 'State Apartment', fig. 60 .

221 See note 219. At Frederiksborg, the tower at the end of the Privy Gallery contained the Audience House. 222 Summerson, 'Building of Theobalds', p. 122. 